published in

Thermal Science and Engineering Progress

available online 23 October 2018 , in press

https://doi.org/10.1016/j.tsep.2018.10.012

\title{
Eco-Innovation in Process Engineering: Contradictions, Inventive Principles and Methods
}

\author{
Pavel Livotov ${ }^{\mathrm{a}}$, Arun Prasad Chandra Sekaran ${ }^{\mathrm{a}}$, Mas'udah ${ }^{\mathrm{a}}$, Richard Law ${ }^{\mathrm{b}}$, David \\ Reay $^{\mathrm{c},}$ Arailym Sarsenova ${ }^{\mathrm{a}}$, Shahin Sayyareh ${ }^{\mathrm{a}}$ \\ a Offenburg University of Applied Sciences, Germany \\ ${ }^{\mathrm{b}}$ Newcastle University, United Kingdom \\ ${ }^{c}$ David Reay \& Associates, United Kingdom
}

\begin{abstract}
Economic growth and ecological problems motivate industries to apply eco-friendly technologies and equipment. However, environmental impact, followed by energy and material consumption still remain the main negative implications of the technological progress in process engineering. Based on extensive patent analysis, this paper assigns more than 250 identified eco-innovation problems and requirements to 14 general eco-categories with energy consumption and losses, air pollution, and acidification as top issues. It defines primary eco-engineering contradictions, in case eco-problems appear as negative side effects of the new technologies, and secondary eco-engineering contradictions, if eco-friendly solutions have new environmental drawbacks. The study conceptualizes a correlation matrix between the eco-requirements for prediction of typical eco-contradictions on example of processes involving solids handling. Finally, it summarizes major eco-innovation approaches including Process Intensification in process engineering, and chronologically reviews 66 papers on eco-innovation adapting TRIZ methodology. Based on analysis of 100 eco-patents, 58 process intensification technologies, and literature, the study identifies 20 universal TRIZ inventive principles and sub-principles that have a higher value for environmental innovation. The presented research work belongs to the European project "Intensified by Design platform for the intensification of processes involving solids handling" (IbD, http://ibd-project.eu), funded by the European Commission under the Horizon 2020 SPIRE programme.
\end{abstract}

Keywords: Eco-engineering contradictions, Eco-innovation, Process engineering, Process intensification, TRIZ.

\section{$1 \quad$ Introduction}

\subsection{Definition of Eco-Engineering Contradictions}

The rapid industrial growth and technological progress of the recent decades created many environmental concerns. As a result, industrial companies become more environmentally responsible, trying to reduce negative ecological impact and potential risks, 
and to apply new eco-friendly technologies. However, implementation of new technologies in process engineering often lead to additional environmental problems, resulting in engineering contradictions [1]. The engineering contradiction is defined as a situation in which the improvement of one parameter (e.g. productivity) implies a deterioration of other parameters (e.g. energy or water consumption) within a system.

Moreover, businesses often choose short to middle-term economic benefits of traditional technologies instead of sustainable and environmental-friendly innovations with economic advantages in the long term only. Applying or developing eco-friendly technologies may be a great challenge for non-green companies because it often requires the acquisition of new resources and competences [2]. Therefore, new technologies in process engineering still demand innovative efforts to reduce environmental issues while increasing economic and technical benefits.

However, even if inventions and new solutions propose an eco-friendly product design or process, additional environmental problems still can appear as negative side effects of obtained solutions, creating a secondary eco-engineering contradiction. The secondary eco-engineering contradiction is a situation where the improvement of ecological parameter causes the worsening of another environmental parameter of a technical system, process, or product.

For example, the invention WO2013165633A1 describes a method to enhance bulk handling properties of pigmentary powder titanium dioxides $\left(\mathrm{TiO}_{2}\right)$. The method increases the bulk density by utilizing ammonia, improves the powder properties, reduces dust formation and waste water disposal. However, the analysis of the proposed solution reveals another eco-problem such as ammonia gas generation which requires specific operations handling safety, accident prevention and environmental care. In another example, the environmentally-friendly method for preparing ceramic powders disclosed in US8765261B2 decreases the amount of carbon waste but generates dust and requires additional measures to prevent air pollution. Thus, two types of eco-engineering contradictions - primary and secondary - can be defined in process engineering or other engineering domains, as shown in Table 1. Further examples of eco-engineering contradictions in process engineering are presented in Table 2.

Table 1. Types of eco-engineering contradictions.

\begin{tabular}{|c|c|c|}
\hline Type of contradiction & Problem situation & Description of contradiction \\
\hline $\begin{array}{l}\text { 1. Primary } \\
\text { eco-contradiction }\end{array}$ & $\begin{array}{l}\text { a) technological innovation } \\
\text { leads to environmental prob- } \\
\text { lems } \\
\text { b) eco-friendly technology } \\
\text { causes additional costs or wors- } \\
\text { ening of technical parameters }\end{array}$ & $\begin{array}{l}\text { a) improvement of non-eco } \\
\text { parameter causes worsening } \\
\text { of eco-parameter } \\
\text { b) improvement of eco-pa- } \\
\text { rameter causes worsening of } \\
\text { non-eco parameter }\end{array}$ \\
\hline $\begin{array}{l}\text { 2. Secondary } \\
\text { eco-contradiction }\end{array}$ & $\begin{array}{l}\text { Eco-friendly technology causes } \\
\text { additional negative environ- } \\
\text { mental impact }\end{array}$ & $\begin{array}{l}\text { improvement of one eco-pa- } \\
\text { rameter causes worsening of } \\
\text { another eco-parameter }\end{array}$ \\
\hline
\end{tabular}

The eco-contradictions are not always evident for the engineers applying new technologies. For example, a support tool for contradiction identification "Contradiction Prompter" is proposed in [3]. As primary eco-contradictions are already the focus of 
attention in industry and society, the secondary eco-contradictions are not systematically analyzed. Therefore, the presented paper has an emphasis on early identification and resolving of secondary eco-contradictions to enable a smooth implementation of new eco-friendly technologies.

Table 2. Examples of primary (PC) and secondary (SC) eco-engineering contradictions.

\begin{tabular}{|c|c|c|c|}
\hline & Invention & Ecological advantages & Negative side effects \\
\hline 1. & $\begin{array}{l}\text { Process of paint sludge re- } \\
\text { cycling } \\
\text { US20140303267A1 }\end{array}$ & $\begin{array}{l}\text { + Decreases chemical } \\
\text { waste disposal in the paint } \\
\text { sludge }\end{array}$ & $\begin{array}{l}\text { - Requires treatment of } \\
\text { gases and vapors which } \\
\text { contain hazardous chemi- } \\
\text { cal compounds (SC) }\end{array}$ \\
\hline 2. & $\begin{array}{l}\text { Method and apparatus of } \\
\text { continuous recovery of } \\
\text { (meth)acrylic acid } \\
\text { (US20150203431A1) }\end{array}$ & $\begin{array}{l}\text { + Reduces energy con- } \\
\text { sumption in the distilling } \\
\text { process of acid }\end{array}$ & $\begin{array}{l}\text { - Higher loss of } \\
\text { (meth)acrylic acid in the } \\
\text { distillation process (SC) } \\
\text { - Increased amount of } \\
\text { waste water (SC) }\end{array}$ \\
\hline 3. & $\begin{array}{l}\text { Method and system for re- } \\
\text { heating flue gas using } \\
\text { waste heat to maintain dry } \\
\text { chimney stack operation } \\
\text { (US20160169510A1) }\end{array}$ & $\begin{array}{l}\text { + Decreases energy con- } \\
\text { sumption } \\
\text { + Minimizes } \mathrm{SO}_{2} \text { emission }\end{array}$ & $\begin{array}{l}\text { - Causes corrosion of the } \\
\text { hot side heat exchanger } \\
\text { (PC) }\end{array}$ \\
\hline 4. & $\begin{array}{l}\text { Counter circulating liquid } \\
\text { processing system by re- } \\
\text { peatedly re-using thermal } \\
\text { energy } \\
\text { (US2017355617A1) }\end{array}$ & $\begin{array}{l}\text { + Reduces energy con- } \\
\text { sumption in thermal distil- } \\
\text { lation of sea water } \\
+ \text { Increase heat exchange } \\
\text { devices efficiency }\end{array}$ & $\begin{array}{l}\text { - Longer process duration } \\
\text { since the apparatus has } \\
\text { multiple stages (PC) }\end{array}$ \\
\hline
\end{tabular}

\section{$1.2 \quad$ TRIZ Methodology}

TRIZ is the internationally acknowledged Russian abbreviation for the Theory of Inventive Problem Solving. The classical TRIZ developed by the Russian scientist G.S. Altshuller (first publication in 1956) and his co-workers [4] has been significantly supplemented in the last two decades [5]. Today TRIZ is considered as one of the most comprehensive, systematically organized invention knowledge and creative thinking methodologies [6]. TRIZ delivers scientifically founded and structured approach to forecasting evolution of engineering systems and includes numerous tools and methods for product and process innovation. For example, the TRIZ Standard of the Association of German Engineers VDI 4521 (2016) [7] contains 25 TRIZ tools for definition of innovation objectives, problem formulation, idea generation and evaluation.

In contrast to the common creativity techniques, only TRIZ relies on the unbiassed laws of evolution of technical systems and enables noticeable increase of creative and inventive productivity. The discovery and structuring of these laws and other TRIZ components have been the result of the study and analysis of globally available patents over a period of several decades. One of the main advantages of TRIZ is that it allows to find new inventive solutions for a given problem in a systematic way by using the 
entire potential of science and engineering, also outside of the field of originally formulated problem.

Besides the central concept of the laws of engineering systems evolution, the identification and uncompromised elimination of engineering contradictions in technical systems, the concepts of Ideality and Ideal Final Result, and the comprehensive mobilization of available resources belong to the fundamentals of TRIZ. Among the most important TRIZ components are

1. 40 inventive principles for eliminating engineering contradictions and system of their application in form of the contradictions matrix (39)39 Altshuller matrix with 39 technical parameters for definition of engineering contradictions).

2. Substance-field analysis and 76 standard solutions for solving technical problems.

3. Step-by-step algorithms for inventive problem solving (abbr.: ARIZ) as a universal tool for solving difficult problems and comprehensive search for solutions.

4. Separation principles for eliminating physical contradictions, i.e. in a situation where one system component should have opposite properties, for example liquid and solid.

5. Resource analysis for analyzing and mobilization of system resources such as time, space, substances, fields (energy), information and functions.

6. Database of physical, chemical, geometrical and other effects and their technical applications.

7. Anticipatory failure identification for analysis and prediction of possible sources of failures.

8. Evolution patterns or trends to forecast the development of technical systems.

9. Creativity enhancing methods, such as operator Size -Time-Cost, "Little people" models, and others.

10. System operator (multi-screen analysis) and function analysis.

In the last two decades, Computer-Aided Innovation tools and new analytical methods for comprehensive problem formulation and contradictions identification have been continuously developed in addition to the classical TRIZ problem-solving tools such as cause-effect-chains analysis and root-conflict analysis [7], problem graph [8], network of contradictions and other TRIZ-related methods, reviewed in [9].

Practically, all these TRIZ tools can be used for solving different tasks and problems of eco-innovation. However, one universal ideation tool appears to be more convenient and favorable for the practical work. For this purpose, the classical 40 Inventive Principles including 88 sub-principles [4] have been extended by additional 72 sub-principles extracted from TRIZ standard solutions, evolution patterns and other inventive operators relevant for process engineering. This enhanced version of 40 inventive principles with 160 sub-principles is used in the presented research and displayed in the Appendix.

In comparison with systematic eco-design tools and green innovation guidelines to assess and overcome negative environmental impacts, only TRIZ offers the methods and tools for identification and elimination of engineering contradictions and helps dramatically enhance the inventive skills of engineers. Therefore, many researches proposed to adapt TRIZ for the domain of eco-innovation in the chemical industry [10], 
for environment-friendly cleaner manufacturing [11], design of green products [12] or eco-design [13].

For example, the authors of [14] adapt the classical TRIZ contradiction matrix with $39 \times 39$ engineering parameters to a $14 \times 14$ matrix to resolve contradictions in process engineering with a set of 8 solution principles. In this matrix 3 of 14 parameters, such as Environmental impact, Hazardous nature, and Process safety can be applied for formulation of 17 primary and 4 secondary eco-engineering contradictions. Another research paper presents a matrix with 6 eco-goals and 21 functional parameters and identifies 63 primary eco-contradictions in 80 patents and 50 products [15]. It shows that eco-contradictions are caused most frequently by the increased energy consumption in new products or processes. The authors of the eco-ideation tool for reduction of greenhouse gas emissions [16] attest TRIZ an important role in eco-innovation.

In this paper 66 eco-innovation methods using elements of TRIZ are briefly reviewed to identify TRIZ tools most frequently applied to environmental problems and in the eco-design approaches. Additionally, the performed patent analysis in the field of eco-innovation and process engineering attempts to identify the typical eco-engineering contradictions with the corresponding strongest TRIZ inventive principles for solving environmental problems, and thus to enhance existing eco-innovation tools.

The presented research work is a part of the European project "Intensified by Design (IbD) platform for the intensification of processes involving solids handling" within a consortium of 22 organisations (research institutes, universities, industrial manufacturers and SMEs) led by IRIS in Barcelona and funded by the European Commission under the Horizon 2020 SPIRE programme [17]. As the IbD project is dealing with processes including pharmaceuticals, ceramics and chemical reactions in the presence of solids, a significant part of performed patent analyses is related to solids handling.

\section{Eco-Problems and Inventive Principles in Patent Literature}

\subsection{Patent Analysis}

The growing importance of patent literature as a source of actual technical information is outlined in numerous scientific works and applications [18, 19, 20]. Numerous studies have shown that, depending on the year and the technical domain, 70-90\% of the technical information can be found only in patent documents [20]. Patent documents in the field of process engineering disclose problems and corresponding solutions also regarding environmental issues $[1,19]$. Thus, selecting and analyzing patents in the field of eco-innovation and process engineering, allows one to systematically extract and to classify environmental requirements and problems addressed by the inventions. On this basis typical eco-engineering contradictions can be identified and used to predict potential secondary eco-problems of new environmentally friendly technologies.

For this purpose, 200 international patent documents with the application date between 2000 and 2017 in the field of process engineering have been analyzed. The patent documents were retrieved by using online search engines and databases of the German Patent and Trade Mark Office (DPMA), the European Patent Office (EPO), and of the 
United States Patent and Trademark Office (USPTO). 150 of the analyzed documents (patents or patent applications) belong to the field of process intensification in the pharmaceutical (50 documents) and ceramic (100 documents) powders processing. Among these 150 solids handling patents, 50 inventions deal with different environmental aspects such as water and energy consumption, air pollution and chemical waste disposal, etc. In addition to the 150 solids handling patents, 50 documents with eco-friendly technologies were retrieved from other domains of process engineering dealing with operations both involving and not involving chemical reactions. The general procedure of the performed patent analysis included the following main steps:

1. Identification of documents with eco-relevant problems or goals of invention.

2. Categorization of the initial problems and their translation to a list of solutionneutral eco-requirements, such as reduce air pollution with dust etc.

3. Extraction of main solution principles as listed in the patent claims and description and their assignment of the corresponding 40 TRIZ inventive principles.

4. Documentation of ecological advantages of the invention by full-text analysis.

5. Identification of ecological disadvantages and other secondary problems of the invention by patent citations according to the method described in [19].

6. Identification of eco-engineering contradictions between the advantages and the secondary problems of inventions.

\subsection{Identification of Environmental Problems in Patent Documents}

The analysis of 100 full-text patent documents solving environmental problems (50 documents related to processes involving solids handling and 50 documents related to other eco-issues in process engineering) has identified 252 ecological requirements or problems: 137 requirements in 50 solids handling patents and 115 requirements in 50 patents related to other eco-issues, as exemplarily presented in Table 3. Depending on the detail level, these ecological requirements and eco-problems can be combined in various groups or categories. A general categorization using 14 environmental impact categories is shown in Table 4. This categorization was proposed according to the international Life Cycle Assessment (LCA) norms ISO 14040:2006, ISO 14044:2006 and Guidelines for Incorporating Eco-Design ISO 14006:2011. It also takes into consideration the 13 criteria of the Process Design for Sustainability (PDfS) and other environmental metrics, summarized in [21].

Table 3. Ecological requirements identified in 100 patents (fragment).

\begin{tabular}{llll}
\hline No. & Solution-neutral eco-requirements & Category & Patent No. \\
\hline 1. & $\begin{array}{l}\text { Reduce formation of effluent water in the } \\
\text { coal gasification process }\end{array}$ & $\begin{array}{l}\text { Water } \\
\text { pollution }\end{array}$ & US 9505999 B1 \\
\hline 2. & $\begin{array}{l}\text { Reduce dust formation in granulation pro- } \\
\text { cess of titania slag }\end{array}$ & Air pollution & WO 2014096541A1 \\
\hline 3. & $\begin{array}{l}\text { Eliminate chemical agents from recycled } \\
\text { paint sludge }\end{array}$ & $\begin{array}{l}\text { Chemical } \\
\text { waste disposal }\end{array}$ & US 20140303267A1 \\
\hline$\ldots$ & $\ldots$ & $\ldots$ & $\ldots$ \\
\hline 252. & $\begin{array}{l}\text { Reduce contamination of breathing air } \\
\text { with powder while filling containers }\end{array}$ & $\begin{array}{l}\text { Safety risks; } \\
\text { Air pollution }\end{array}$ & WO 2013044921A2 \\
\hline
\end{tabular}


In such classification one ecologically critical agent or substance can be simultaneously assigned to various categories. For instance, ammonia $\left(\mathrm{NH}_{3}\right)$ not only causes eutrophication (cat. 8), but it also has further problems such as acidification, toxicity and photochemical oxidation (cat. 3, 7, 9 respectively).

Interestingly, thermal process technologies and equipment are responsible for the major eco-problem category Energy consumption, which was mentioned in total 50 times in 100 eco-patents: 38 times as an invention task and 12 times as a negative side effect.

Table 4. Categories and number of eco-problems mentioned in 100 eco-patents.

\begin{tabular}{|c|c|c|c|}
\hline No & Category & Description & $\begin{array}{c}\text { Num- } \\
\text { ber }\end{array}$ \\
\hline 1 & $\begin{array}{l}\text { Energy } \\
\text { consumption }\end{array}$ & $\begin{array}{l}\text { High amount of energy used in chemical processes } \\
\text { (e.g. thermal distillation), large amount of energy } \\
\text { wasted as heat }\end{array}$ & 50 \\
\hline 2 & Air pollution & $\begin{array}{l}\text { Fly ash generation, particulate matters formation (dust, } \\
\text { smog), global warming (greenhouse gas emissions) }\end{array}$ & 45 \\
\hline 3 & Acidification & $\begin{array}{l}\text { Acidic gases emissions }\left(\mathrm{SO}_{2} \& \mathrm{CO}_{2}\right) \text {, acid rain emis- } \\
\text { sions }\left(\mathrm{H}_{2} \mathrm{SO}_{4} \& \mathrm{HNO}_{3}\right), \mathrm{NH}_{3} \text { and } \mathrm{NO}_{\mathrm{X}} \text { emissions }\end{array}$ & 26 \\
\hline 4 & Safety risks & $\begin{array}{l}\text { Flammability risk, high pressure and temperature, va- } \\
\text { por cloud explosion }\end{array}$ & 21 \\
\hline 5 & $\begin{array}{l}\text { Chemical waste } \\
\text { disposal }\end{array}$ & $\begin{array}{l}\text { Chemical hazardous waste disposal (organic perox- } \\
\text { ides, flammable gases, corrosive substances) }\end{array}$ & 20 \\
\hline 6 & $\begin{array}{l}\text { Depletion of } \\
\text { abiotic resources }\end{array}$ & Land, water, air depletion & 20 \\
\hline 7 & Toxicity & $\begin{array}{l}\text { Human toxicity, hazardous chemical waste (ammonia, } \\
\text { phosphates, fragrance chemicals), eco toxicity (fresh } \\
\text { water, marine and land toxicity) }\end{array}$ & 19 \\
\hline 8 & Eutrophication & $\begin{array}{l}\text { Degradable organic substances and surplus nitrogen } \\
\text { e.g. } \mathrm{NO}_{3-}, \mathrm{NO}_{\mathrm{x}} \text { and } \mathrm{NH}_{3} \text { emissions }\end{array}$ & 15 \\
\hline 9 & $\begin{array}{l}\text { Photochemical } \\
\text { oxidation }\end{array}$ & $\mathrm{NO}, \mathrm{CO}, \mathrm{SO}_{2}$ and ammonium emissions & 12 \\
\hline 10 & Water pollution & $\begin{array}{l}\text { Groundwater pollution, thermal pollution, pollution } \\
\text { with chemicals such as hazardous chemical agents and } \\
\text { solvents disposal }\end{array}$ & 11 \\
\hline 11 & Solid Waste & $\begin{array}{l}\text { Saturated waste limestone powder, concentrated } \\
\text { sludge }\end{array}$ & 5 \\
\hline 12 & Radioactivity & Radioactive materials leakage & 4 \\
\hline 13 & $\begin{array}{l}\text { Ozone layer } \\
\text { depletion }\end{array}$ & $\begin{array}{l}\text { Chlorofluorocarbons (CFCs) and Hydrochlorofluoro- } \\
\text { carbons (HCFCs) emissions to atmosphere }\end{array}$ & 3 \\
\hline 14 & $\begin{array}{l}\text { Raw material } \\
\text { intensity }\end{array}$ & High raw material usage & 1 \\
\hline
\end{tabular}

The separate evaluation of eco-problems frequency in 50 eco-patents dealing with ceramic and pharmaceutical powders processing and in 50 eco-patents in process engineering dealing with operations involving and not involving chemical reactions is presented in Fig. 1. The categories 1. Energy consumption and 2. Air pollution are the most 
frequently mentioned as primary or secondary problems in the analyzed patent literature. On the other hand, category 3. Acidification rarely appears in solids handling patents, this contrasting with the patents related to eco-problems in process engineering.

The 14 environmental categories allow one to check in detail the possible ecological impact of new technologies and equipment and to formulate resulting eco-engineering contradictions. The presented results can be refined if the level of detailing for ecocategories is changed to a higher number of individual categories. Once determined, the identified ecological advantages and disadvantages of inventions allow one to zoom dynamically into a problem situation with required resolution and to identify the root causes of the occurring eco-problems.

50 patents related to solids handling

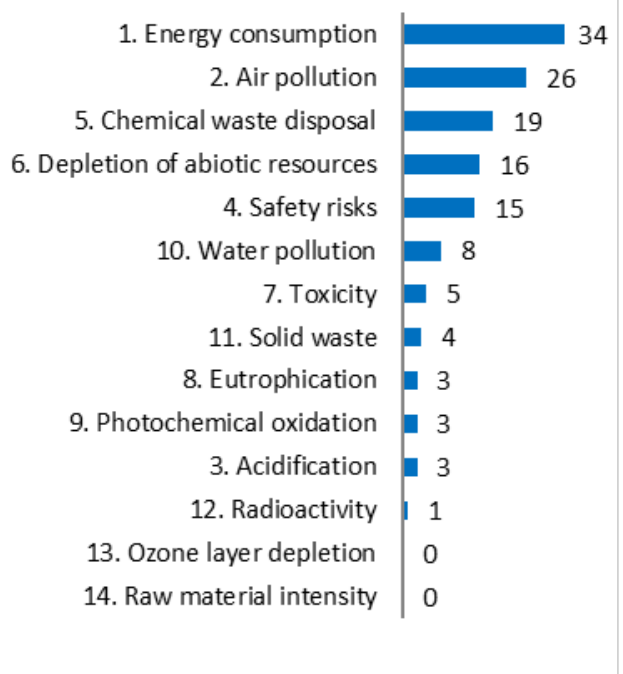

50 patents related to eco-problems in PE

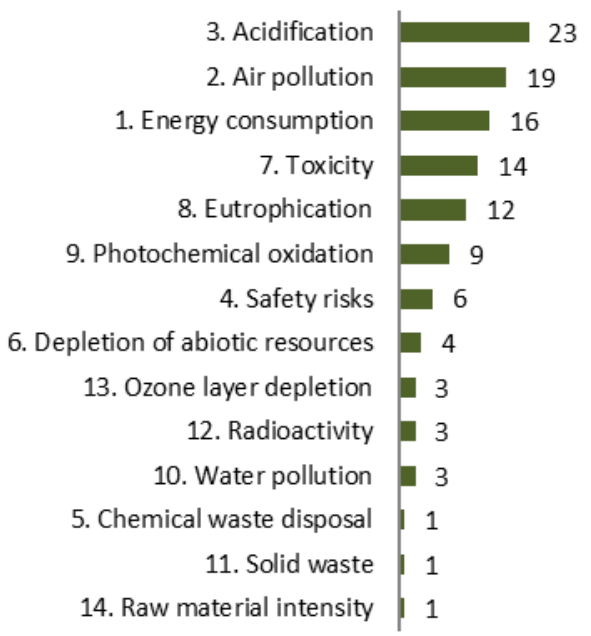

Fig. 1. Eco-problems mentioned in solids handling and other process engineering (PE) patents (based on the analysis of 100 eco-patents; multiple assignment).

The performed analysis of 150 patent documents in the field of pharmaceutical (50 documents) and ceramic (100 documents) powders processing gave an opportunity to identify 208 typical invention tasks and requirements of process intensification (PI) involving solids handling. These identified demands represent economic, technical and environmental aspects, such as, for example, increase productivity, avoid agglomeration of powder, enhance mechanical stability of granules, avoid fouling and clogging, minimize labour-consuming maintenance, and others. Like the evaluation of eco-patents presented above, these 208 requirements can be assigned to a lower number of process intensification categories for solids handling.

The following 27 categories have been proposed by the authors in [19]: Productivity, Investment costs, Solids handling efforts, Process duration, Production capacity, Size 
of equipment, Complexity, Controllability, Reliability, Adaptability of equipment, Replaceability of equipment, Maintenance and cleaning, Quality of product, Mechanical properties, Chemical properties, Physical properties, Uniformity, Disintegration, Agglomeration, Moisture content, Product composition, Homogeneity, Energy consumption, Water consumption, Process efficiency, and Environmental performance.

Due to the patent analysis it is possible to compare the number of inventive tasks and advances with the quantity of secondary problems in each category. The Figure 2 shows the top five categories with the highest number of secondary problems in 150 solids handling patents. The important finding of this study is that the most frequent secondary side effects encountered in the inventions are of an ecological nature, these being the negative environmental impact (131 times), higher water or material consumption (65 times), and higher energy consumption (57 times). On the other hand, the inventive goals in the patent literature are mainly related to the quality parameters of the product and its mechanical, physical and chemical properties.

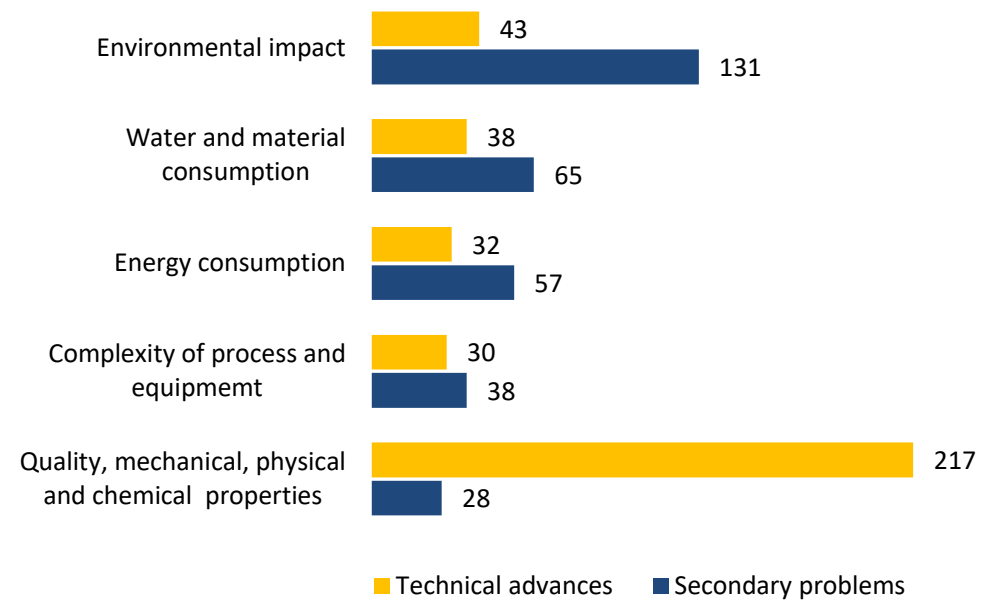

Fig. 2. Technical advances and initial problems solved by the inventions and new secondary problems (disadvantages), identified from 150 solids handling patents (number of mentioning, multiple assignment).

Such a situation leads inevitably to numerous primary eco-engineering contradictions in solids processing between environmental categories (environmental impact, energy and material consumption) and other economic and technical categories (cost, quality of product, complexity of process and equipment etc.). A correlation matrix $27 \times 27$ build with 27 process intensification categories relating to solids handling mentioned above is presented in [19]. This matrix presents 215 primary eco-contradictions identified in the 150 solids handling patents. 


\subsection{Identification of Environmental Problems in Case Studies}

To verify the findings from the patent analysis, the environmental problems of existing technologies, dealing with continuous drying process in pharmaceutical tablet manufacturing and granulation process in ceramic industry, have been identified using the process mapping method.

Process mapping [22] is an easy-to-use technique to identify innovation tasks and solution-neutral process intensification requirements in existing processes. The method involves breaking down of a complete industrial production process into process steps to capture in each step the information on process equipment, processing methods, input/output quality parameters, product, available resources, and environment, as in detail presented in Figure 3. Process mapping results in comprehensively capturing and ranking of all existing problems, formulated as enhancement of positive functions or effects, elimination of negative functions, effects or undesired properties, raising degree of controllability, accuracy, and automation of the process step.

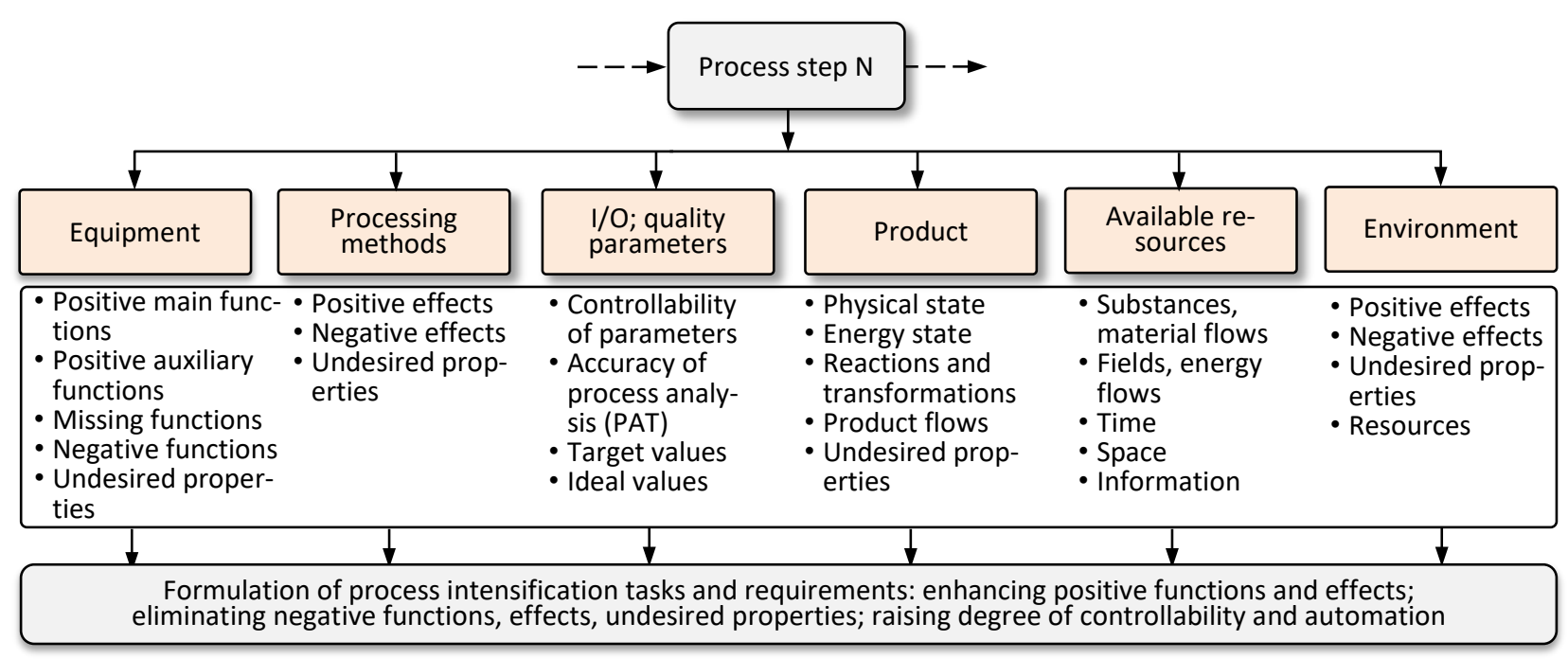

Fig. 3. Process mapping technique: fragment, adapted from [22].

The results of the pharmaceutical and ceramic powder processing case studies examined in the IbD HORIZON 2020 project [17] are briefly presented in Table 5. In both case studies 22 environmental problems constitute $29 \%$ of all problems. Eco-problems related to the Energy consumption category are in the first place with $36 \%$, followed by the Air pollution (32\%), Water pollution and consumption (23\%), and Raw material losses $(9 \%)$. These analyses show a good correlation between the occurrences of environmental problems in the case studies and in the evaluated eco-patents (see Table 4). 
Table 5. Identification of environmental problems in case studies.

\begin{tabular}{lcccccc}
\hline Case study & Problems & \multicolumn{5}{c}{ Environmental problems } \\
\hline $\begin{array}{c}\text { Total } \\
\text { amount }\end{array}$ & $\begin{array}{c}\text { Energy } \\
\text { consump- } \\
\text { tion }\end{array}$ & $\begin{array}{c}\text { Air pol- } \\
\text { lution }\end{array}$ & $\begin{array}{c}\text { Water } \\
\text { pollu- } \\
\text { tion, con- } \\
\text { sumption }\end{array}$ & $\begin{array}{c}\text { Raw } \\
\text { mate- } \\
\text { rial } \\
\text { losses }\end{array}$ & Total \\
\hline $\begin{array}{l}\text { 1. Continuous dry- } \\
\text { ing process in phar- } \\
\text { maceutical industry }\end{array}$ & 32 & 3 & 2 & 2 & - & 7 \\
\hline $\begin{array}{l}\text { 2. Granulation pro- } \\
\text { cess in ceramic in- } \\
\text { dustry }\end{array}$ & 45 & 5 & 5 & 3 & 2 & 15 \\
\hline $\begin{array}{l}\text { Total amount of } \\
\text { problems }\end{array}$ & 77 & 8 & 7 & 5 & 2 & 22 \\
\hline
\end{tabular}

\subsection{Correlation Matrix of Eco-Requirements}

As reported above, the identification of the secondary eco-engineering contradictions between different environmental parameters required a more detailed analysis of the 100 patent documents with ecological goals of inventions, which were assigned to 14 environmental categories. The obtained information about existing correlations between the initial eco-problems to be solved by the inventions and the corresponding secondary eco-problems can be used to build a correlation matrix predicting secondary eco-contradictions in the field of analysis. Contrary to the deterministic definition of contradictions used in the classical TRIZ, the identified contradictions are expected here with a certain degree of probability. A fragment of correlation matrix with 14 environmental categories is presented in Table 6, where "-1" indicates a possible negative impact and thus a secondary eco-contradiction, " +1 " indicates a positive impact, and " 0 " - a neutral or unknown counteraction between two eco-categories. In other words, the correlation matrix helps engineers to see how one improved eco-parameter can affect the other eco-parameters either positively or negatively. For example, reduction of Toxicity (7) has positive impact on Water pollution (10) but can negatively affect Air pollution (2), for example, by use of sorbents. The matrix displays 35 secondary ecocontradictions, which can be resolved by TRIZ inventive principles.

As mentioned in section 2.2 , the presented $14 \times 14$ correlation matrix can be dynamically displayed with higher resolution up to $252 \times 252$ individual eco-requirements, giving more precise recommendations for possible secondary eco-engineering contradictions. Such a dynamic correlation matrix based on patent analysis can combine various levels of abstractions or generalization and increase the accuracy and reliability of ecological impact assessments for new technologies. 
Table 6. Correlation matrix with identified environmental problems and secondary eco-contradictions: "-1" negative impact (eco-contradiction); "+1" positive impact; "0" - neutral

\begin{tabular}{|c|c|c|c|c|c|c|c|c|c|c|c|c|c|}
\hline \multirow{2}{*}{\multicolumn{2}{|c|}{$\begin{array}{l}\text { Eco-parameters } \\
\text { to be improved: }\end{array}$}} & \multicolumn{12}{|c|}{ Eco-parameter changed for the worse (secondary impact): } \\
\hline & & \multirow[t]{2}{*}{1} & \multirow{2}{*}{$\begin{array}{l}2 \\
-1\end{array}$} & \multirow{2}{*}{$\begin{array}{c}3 \\
+1\end{array}$} & \multirow{2}{*}{$\begin{array}{c}4 \\
-1\end{array}$} & \multirow{2}{*}{$\begin{array}{c}5 \\
-1 \\
\end{array}$} & \multirow{2}{*}{$\begin{array}{c}\mathbf{6} \\
-1 \\
\end{array}$} & \multirow{2}{*}{$\begin{array}{c}7 \\
+1\end{array}$} & \multirow{2}{*}{$\begin{array}{c}\mathbf{8} \\
+1\end{array}$} & \multirow{2}{*}{$\begin{array}{c}9 \\
+1\end{array}$} & \multirow{2}{*}{$\begin{array}{c}\mathbf{1 0} \\
-1 \\
\end{array}$} & \multirow{2}{*}{$\begin{array}{l}11 \\
+1\end{array}$} & \multirow{2}{*}{$\frac{12}{0}$} \\
\hline 1 & \begin{tabular}{|l|} 
Energy \\
consumption
\end{tabular} & & & & & & & & & & & & \\
\hline 2 & Air pollution & -1 & & +1 & -1 & -1 & -1 & -1 & +1 & +1 & -1 & -1 & 0 \\
\hline 3 & Acidification & -1 & +1 & & -1 & 0 & -1 & -1 & +1 & +1 & 0 & +1 & 0 \\
\hline 4 & Safety risks & -1 & -1 & 0 & & -1 & -1 & +1 & +1 & 0 & -1 & -1 & 0 \\
\hline 5 & $\begin{array}{l}\text { Chemical waste } \\
\text { disposal }\end{array}$ & -1 & -1 & 0 & +1 & & +1 & +1 & +1 & 0 & 0 & 0 & 0 \\
\hline 6 & $\begin{array}{l}\text { Depletion of } \\
\text { abiotic resources }\end{array}$ & -1 & -1 & +1 & 0 & +1 & & +1 & +1 & +1 & -1 & +1 & -1 \\
\hline 7 & Toxicity & +1 & -1 & 0 & +1 & +1 & +1 & & +1 & 0 & +1 & 0 & 0 \\
\hline 8 & Eutrophication & +1 & +1 & +1 & +1 & +1 & +1 & +1 & & +1 & 0 & 0 & 0 \\
\hline 9 & \begin{tabular}{|l|}
$\begin{array}{l}\text { Photochemical } \\
\text { oxidation }\end{array}$ \\
\end{tabular} & +1 & -1 & +1 & 0 & -1 & -1 & 0 & +1 & & 0 & 0 & 0 \\
\hline 10 & Water pollution & +1 & +1 & 0 & 0 & 0 & +1 & +1 & 0 & 0 & & 0 & 0 \\
\hline 11 & Solid Waste & -1 & +1 & +1 & +1 & -1 & +1 & 0 & 0 & 0 & -1 & & 0 \\
\hline 12 & Radioactivity & 0 & 0 & 0 & 0 & 0 & 0 & 0 & 0 & 0 & 0 & 0 & \\
\hline 13 & $\begin{array}{l}\begin{array}{l}\text { Ozone layer } \\
\text { depletion }\end{array} \\
\end{array}$ & 0 & 0 & 0 & 0 & 0 & 0 & 0 & 0 & 0 & 0 & 0 & 0 \\
\hline 14 & $\begin{array}{l}\text { Raw material } \\
\text { intensity }\end{array}$ & 0 & 0 & 0 & 0 & 0 & 0 & 0 & 0 & 0 & 0 & 0 & 0 \\
\hline
\end{tabular}

\subsection{TRIZ Inventive Principles extracted from Eco-Patents}

Identification of TRIZ inventive principles used in 100 patent documents dealing with ecological problems in the field of process engineering was a part of this study. The top 10 inventive principles and sub-principles most frequently used in the analyzed patent literature to solve eco-problems are presented in Fig. 4. There is a significant difference between the top 10 principles for eco-problems and the top 10 principles encountered in the 155 process intensification technologies (N14, 29, 35, 2, 5, 36, 6, $28,24,18)$ [23] with only 3 similar principles N29, 35 and 3 . Also a comparison of the top 10 principles for eco-problems (Fig. 4) with the statistically strongest and most often applicable inventive principles [24] (N35, 10, 1, 28, 2, 15, 19, 3, 17, 13 - see appendix) outlines only 4 similar principles $\mathrm{N} 35,1,2,15$. 


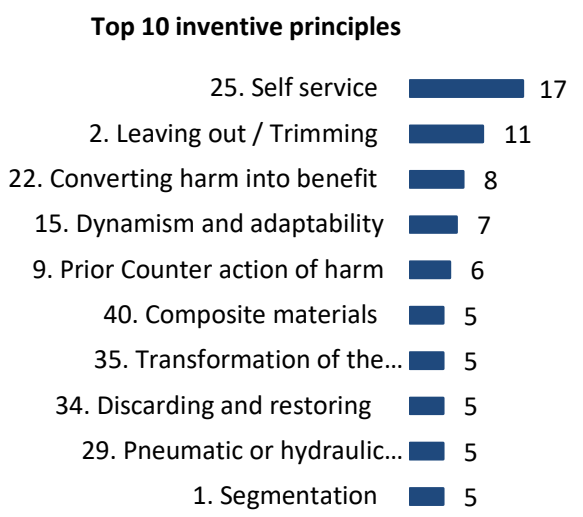

Top 10 inventive sub-principles

2(a) Take out disturbing parts

25(b) Utilize waste resources

22(a) Utilize harm 8

25(a) Object serves itself 6

34(a) Discard useless parts $\square 4$

33(a) Similar materials $\quad 4$

29(a) Gaseous or liquid flows 4

21(a) Skip hazardous... 4

15(a) Optimal performance $\quad 4$

40(a) Composite materials 3

Fig. 4. Top 10 most frequently used TRIZ inventive principles and sub-principles extracted from 100 eco-patents (application frequency in 100 patents in \%)

Reducing energy consumption and heat losses belong to one of the central environmental goals in process engineering. For that reason, the additional analysis of selected 38 eco-patents with this inventive task has been performed to identify typical solution principles applied to new technologies or equipment. The results outline two of the strongest principles especially for thermal and heat transfer processes: N25. Self-service (utilize waste or environmental resources) and N22. Converting harm into benefit. One application example of Principle 25. Self-service is given in US2017355617A1 which reduces energy consumption in thermal liquid desalination and distillation by repeatedly re-using thermal energy in the system. Another recent research study [25] examines the intensification of carbon capturing in the cement and iron/steel production using a temperature $\mathrm{CO}_{2}$ adsorption process involving swirling or toroidal fluidized beds: the recovered waste heat in the cement and iron/steel processes can be used to cover high energy needs of the temperature swing adsorption.

\subsection{Inventive Principles for Resolving Eco-Engineering Contradictions identified with the Contradiction Matrix}

The classical 39x39 TRIZ Contradiction Matrix, also known as Altshuller Matrix [4], with 39 engineering parameters can be also used for identification of the inventive principles for eco-engineering contradictions with 5 ecologically relevant parameters, such as Energy consumption of the moving object (n.19), and of the non-moving object (n.20), Energy losses (n.22), Material losses (n.23), Amount of substance (n.26). All 39 parameters, including 5 eco-parameters and other 34 non-ecological parameters, together with instructions on how to apply the Altshuller Matrix are available on-line in [24]. 
In accordance with our analysis the 39x39 TRIZ matrix proposes solution principles for 281 primary and 15 secondary eco-contradictions regarding efficiency of energy or material utilization. The diagrams in Figure 5 present the top 10 TRIZ inventive principles recommended with the matrix for resolving

a) 65 primary eco-contradictions resulting from improvement of parameters $E n$ ergy consumption of the moving object (n.19), Energy consumption of the nonmoving object (n.20), and Energy losses (n.22) on the one hand, and worsening of the other 34 non-ecological parameters on the other hand.

b) 64 primary eco-contradictions resulting from improvement of parameters $\mathrm{Ma}$ terial losses (n.23), Amount of substance (n.26) on the one hand, and worsening of the other 34 non-ecological parameters of the matrix on the other hand.
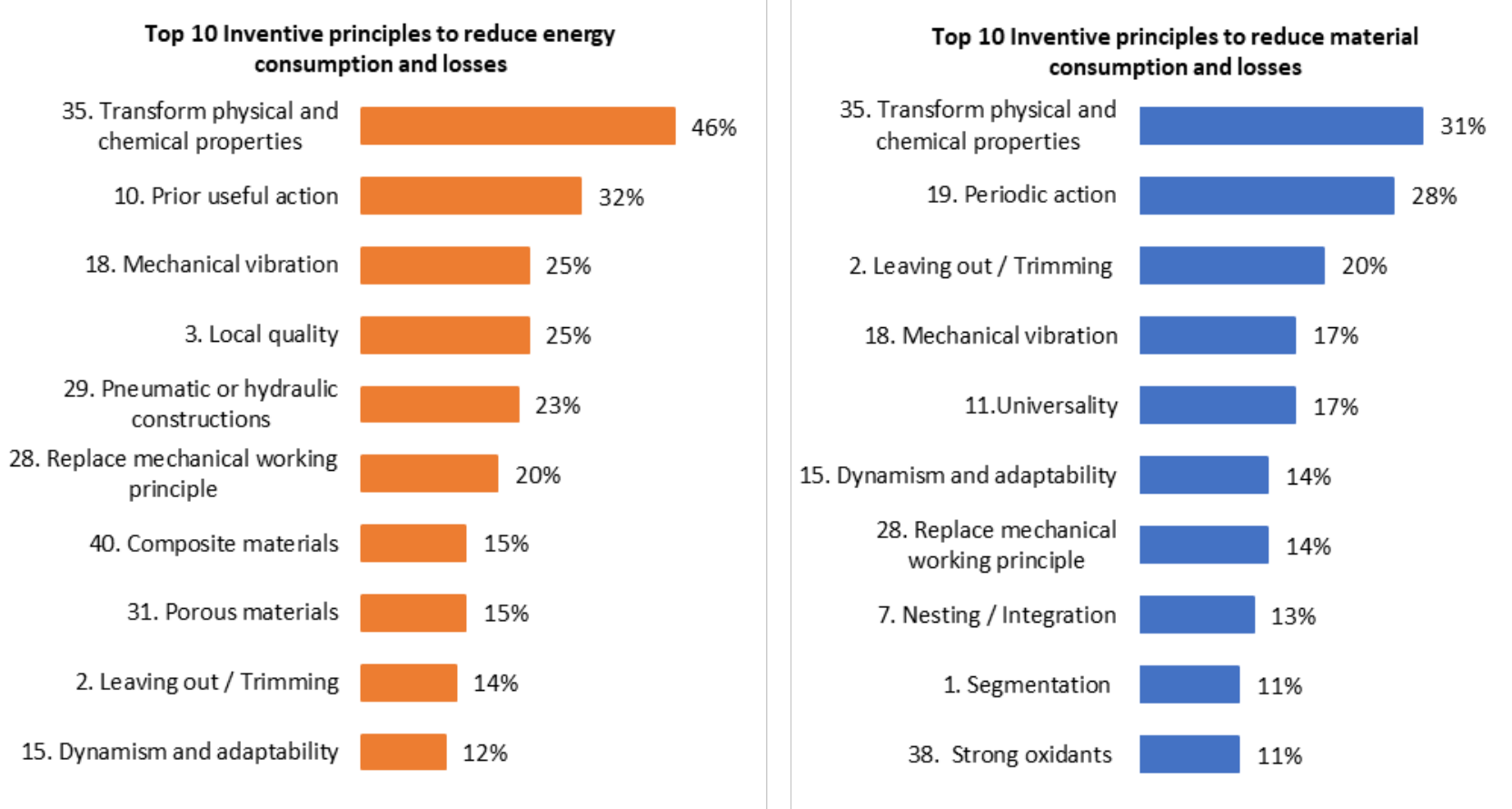

Fig. 5. Top 10 TRIZ inventive principles for primary eco-contradictions in order of their recommendation frequency by the $39 \times 39$ Contradiction Matrix

Comparing matrix recommendations in Fig. 5 with the inventive principles extracted from the list of eco-patents (Fig. 4) a low overlapping of these top 10 principles groups must be taken into account. Moreover, the application of the classical TRIZ matrix for other eco-innovation requirements is limited. An attempt to update the matrix and to increase the original list of 39 parameters to 50 was undertaken in 2003 and resulted in two additional eco-parameters such as Noise and Harmful emissions [26].

In general, a successful application of TRIZ inventive principles in eco-innovation requires higher qualification and creativity of engineers and needs methodical support. 
Therefore, the existing approaches combining eco-design guidelines with TRIZ should enable engineers to identify and implement appropriate solutions faster in accordance with the objectives and constraints of their development tasks.

\section{Eco-Innovation Methods using TRIZ}

\subsection{Brief Definitions of Eco-Design and Eco-Innovation}

Eco-Design can be defined as an approach to improve or develop products or processes under consideration their environmental impacts during their entire lifecycle. The ecoinnovation focuses on the integration of environmental aspects and requirements in the early stages of the innovation and new product development processes. In accordance to [27] eco-innovation includes "new or modified processes, practices, systems and products which benefit the environment and contribute to environmental sustainability". The International Organization for Standardization ISO issued numerous norms, guidelines, and tools. For example, the ISO14040:2006 describes the principles and framework for life cycle assessment (LCA), ISO14044:2006 provides LCA guidelines, and ISO14006:2011 provides guidelines to implement Eco-Design as part of an environmental management system (EMS) within companies.

A number of methods and tools have been developed to support the process of ecoinnovation in the last two decades. To the best-known methods belong Eco-Compass [28], Life Cycle Design Strategy (LiDS Wheel) [29], Sustainability Circle [30], EcoDesign PILOT [31], Eco-Ideation Tool [16], Value Mapping Tool [32], Design for Environment (DfE) [33] and Quality Function Deployment for Environment (QFDE) [34, 35], EcoASIT [36], Eco-ideation stimulation meso-mechanisms ESMs [37], Green Engineering [38] with 12 Principles of Green Engineering [39], and other methods, presented in a comparative study of strategy- and ideation-oriented eco-innovation tools [40]. In the field of process engineering should be mentioned in first place Green Process Engineering [41] and Process Intensification (PI) [42], Process Design for Sustainability (PDfS) [21], and other approaches.

\subsection{Process Intensification as a Knowledge-based Eco-Engineering Methodology}

Process Intensification (PI) can be generally defined as a knowledge-based methodology leading to more efficient processes and equipment, characterised by reduced energy consumption and losses, raw material cost reduction, increased process flexibility, quality, safety, and better environmental performance [43, 42]. The concept of Process Intensification dates back to the research of Prof. Ramshaw and his colleagues [44, 45] and subsequently became more diverse in its implementation and practice, from the processes mainly involving gas/liquid systems to the solids handling [46]. Its modern application is not only limited to the chemical engineering and now includes environmental aspects of process engineering [42] and challenges of heat and mass transfer $[25,47]$. 
The PI technological databases are continuously evolving and currently cover a wide range of more than 155 processing methods and equipment, such as equipment carrying out chemical reactions, operations not involving chemical reactions, multifunctional reactors, hybrid separation methods, alternative energy sources and others [42, 46]. As high energy consumption and energy losses were found as most frequently mentioned negative side effects in eco-engineering contradictions, the following 58 PI thermal operations and technologies, presented in Table 7, can be recommended for systematic solving of eco-problems.

Table 7. Example of 58 thermal operations, methods and equipment in Process Intensification

\begin{tabular}{|l|l|}
\hline \multicolumn{1}{|c|}{$\begin{array}{c}\text { Thermal opera- } \\
\text { tion / equipment }\end{array}$} & \multicolumn{1}{c|}{ PI technologies } \\
\hline Reactors (11) & $\begin{array}{l}\text { Catalytic Plate Reactor (CPR), Heat Pipe Reactor, General HEX- } \\
\text { Reactors, Alfa-Laval Plate Heat Exchanger Reactor, Heatric Diffusion } \\
\text { Bonded Reactors, MarBond Reactor, Multiple Adiabatic-Bed PCR, } \\
\text { Reverse Flow Reactor, ShimTec Compact HEX-Reactor, HiGee (Ro- } \\
\text { tating Packed Bed), Static mixers }\end{array}$ \\
\hline Distillation (10) & $\begin{array}{l}\text { Reactive Distillation, Pervaporation-Assisted Reactive Distillation, } \\
\text { Distillation - Dividing Wall Column, Cyclic Distillation, Fixed-Bed } \\
\text { Adsorptive (FAD) Distillation, Suspension Adsorptive (SAD) Distil- } \\
\text { lation, Extractive Distillation, Heat-Integrated Distillation, Membrane } \\
\text { Distillation, Distillation - Pervaporation }\end{array}$ \\
\hline $\begin{array}{l}\text { Heat transfer equip- } \\
\text { ment (8) }\end{array}$ & $\begin{array}{l}\text { Nano-Fluids for Enhanced Heat Transfer, Additives (for Liq- } \\
\text { uids/Gases) for Enhanced Heat Transfer, Treated Surface (Coatings) } \\
\text { for Enhanced Heat Transfer, Extended Surfaces for Enhanced Heat } \\
\text { Transfer, Acoustically Enhanced Boiling Heat Transfer, Surface Vi- } \\
\text { bration for Enhanced Heat Transfer, Ultrasonic Fluid Vibration for En- } \\
\text { hanced Heat Transfer, Electrostatic Fields for Enhanced Heat Transfer }\end{array}$ \\
\hline Heat exchangers (7) & $\begin{array}{l}\text { Plate Heat Exchanger, Printed Circuit Heat Exchanger (PCHE), Chart- } \\
\text { flo Heat Exchanger, Polymer Film Heat Exchanger, Foam Heat Ex- } \\
\text { changer, Mesh Heat Exchanger, Micro Heat Exchanger }\end{array}$ \\
\hline Crystallization (6) & $\begin{array}{l}\text { Reactive Crystallization/Precipitation, Ultrasound-Enhanced Crystal- } \\
\text { lization, Electric Field-Enhanced Crystallization, Electrostatic Precip- } \\
\text { itation (ESP), Extractive Crystallization, Membrane Crystallization }\end{array}$ \\
\hline Heating (5) & $\begin{array}{l}\text { Radio Frequency (RF) Heating, Microwave Heating, Induction Heat- } \\
\text { ing, Plasma Heating, Viscous Heating Devices }\end{array}$ \\
\hline Extraction (4) & $\begin{array}{l}\text { Reactive Extraction, Centrifugal Liquid-Liquid Contactors, Electric } \\
\text { Field-Enhanced Extraction, Membrane Extraction }\end{array}$ \\
\hline Drying (4) & $\begin{array}{l}\text { Electric Drying and Dewatering, Membranes for Dehydration, } \\
\text { Microwave Heating + Drying, Pulsed Combustion Drying }\end{array}$ \\
\hline Reactive Condensation \\
Cryogenic Separation \\
Plasma gasification (1)
\end{tabular}

The top 10 TRIZ inventive principles and sub-principles, extracted from thermal PI technologies are presented in Fig. 6. They can be generally recommended for solving of eco-problems related to energy consumption and losses in process intensification. 
Top 10 inventive principles

35. Transform physical and chemical...

$$
\text { 5. Combining }
$$

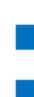

2. Leaving out / Trimming

29. Pneumatic or hydraulic...

...

28. Replace mechanical working...

36. Phase transitions

$$
\text { ... }
$$

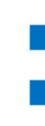

20. Continuity of useful action

30. Flexible shells or thin films

24. Mediator

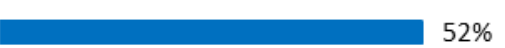

$41 \%$
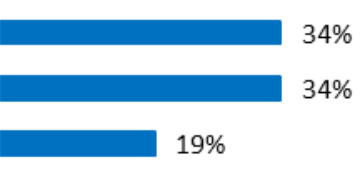

$19 \%$

$14 \%$

$14 \%$

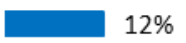

$12 \%$
Top 10 inventive sub-principles

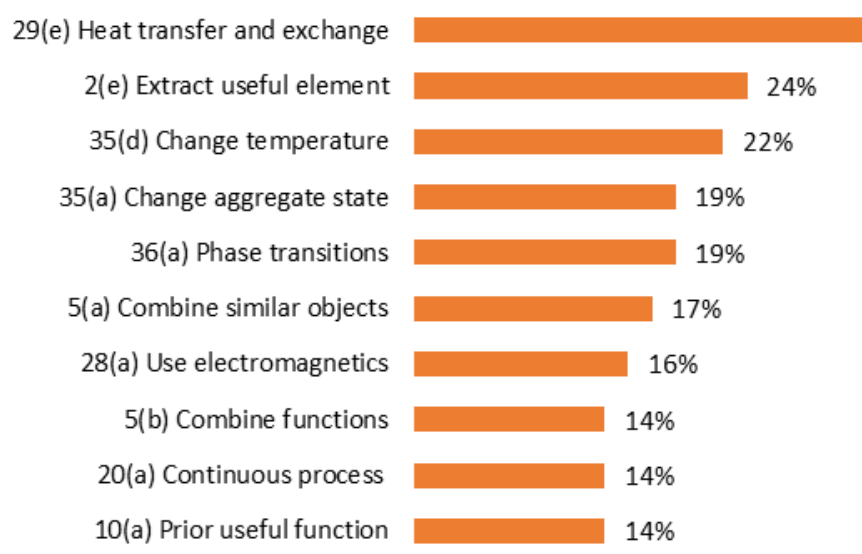

Fig. 6. Top 10 TRIZ inventive principles and sub-principles most frequently encountered in the 58 analyzed thermal operations and methods, presented in Table 7

It is also important to note here that some technological basics of PI $[41,46]$ are similar to the evolution laws and inventive principles of TRIZ [1]. For example, transition of operations from the macro- to meso- and micro-level as well as enhanced surface configurations known in PI, correspond to the TRIZ inventive principle 17. Shift to another dimension (17b. Miniaturization; 17e. Two- and three-dimensional interactions). The PI principle of the force fields enhancement (mechanical - acoustic - electrical - electromagnetic - light energy) is equivalent to the TRIZ principle 28. Replace mechanical working principle. Reasonably, that the PI researchers, then being unaware of TRIZ, could empirically propose conceptual techniques similar to TRIZ. For example, the majority of 15 process intensification strategies presented in [48] show parallels to some TRIZ inventive principles. Table 8 illustrates advantageous synergies of TRIZ and PI. In general, TRIZ inventive principles as more abstract and universal, whilst some of the intensification strategies in [48] can be seen as detailed illustrations or interpretations of TRIZ principles. 
Table 8. Comparison of intensification strategies [48] with 40 TRIZ Inventive Principles.

\begin{tabular}{|c|c|}
\hline 15 PI strategies, adapted from [48] & 40 TRIZ Inventive Principles $[4,23]$ \\
\hline $\begin{array}{l}\text { 1. Modification of operating conditions: tem- } \\
\text { perature, pressure, concentration } \\
\text { 2. New solvents to reduce environmental im- } \\
\text { pact of processes } \\
\text { 3. Modification of fluid phase properties by } \\
\text { change of pressure or temperature } \\
\text { 6. Catalyst structuring and modification } \\
\text { 8. Increasing shear rate } \\
\text { 9. Change of material properties }\end{array}$ & $\begin{array}{l}\text { 35. Transformation of the physical and } \\
\text { chemical properties: } \\
\text { a) Change an object's aggregate state } \\
\text { b) Change the object's concentration or con- } \\
\text { sistency. } \\
\text { c) Change other relevant physical properties } \\
\text { or operational conditions (pressure, density, } \\
\text { hardness, viscosity, conductivity, mag- } \\
\text { netism etc.), separately or together. } \\
\text { d) Change the object's temperature. } \\
\text { e) Change process chemistry, chemical } \\
\text { properties or operational conditions: formu- } \\
\text { lation, pH, solubility etc. }\end{array}$ \\
\hline $\begin{array}{l}\text { 3. Modificat } \\
\text { addition of } g\end{array}$ & $\begin{array}{l}\text { 40. Composite materials: composition of } \\
\text { materials in different aggregate states }(40 \mathrm{e})\end{array}$ \\
\hline $\begin{array}{l}\text { 4. Inert speci } \\
\text { emulsifying a }\end{array}$ & $\begin{array}{l}\text { ent. } \\
\text { mediate object (24a) }\end{array}$ \\
\hline $\begin{array}{l}\text { 5. Geometric-structuring strategy and micro } \\
\text { structuring, }\end{array}$ & $\begin{array}{l}\text { 17. Shift to another dimension: multi-dimen- } \\
\text { sional interactions }(17 \mathrm{e}) \text {, miniaturization } \\
(17 \mathrm{~b})\end{array}$ \\
\hline 7. Gravity & $\begin{array}{l}\text { 8. Anti-weight: use of gravitational or cen- } \\
\text { trifugal force }(8 \mathrm{~d})\end{array}$ \\
\hline $\begin{array}{l}\text { 10. Parallelism in the process, multi-scale de- } \\
\text { sign } \\
\text { 15. Coupling with separation }\end{array}$ & $\begin{array}{l}\text { 5. Combining: parallel operations }(5 \mathrm{a}) \text {, } \\
\text { combine process steps to perform parallel or } \\
\text { contiguous operations }(5 \mathrm{~b})\end{array}$ \\
\hline 11. Segmentation, non-uniform conditions. & $\begin{array}{l}\text { 1. Segmentation } \\
\text { 3. Local quality: non-uniform structure or } \\
\text { properties ( } 3 a \text { ) }\end{array}$ \\
\hline 12. Periodic operation & 19. Periodic action \\
\hline $\begin{array}{l}\text { 13. Phase contacting: choice of optimal resi- } \\
\text { dence time distribution to operate a reaction }\end{array}$ & $\begin{array}{l}\text { 15. Dynamism / Adaptability: enable opti- } \\
\text { mal performance parameter at each stage of } \\
\text { operation (20a) }\end{array}$ \\
\hline 14. Alternative energy sources & $\begin{array}{l}25 \text {. Self-service: use of waste }(25 b) \text { and en- } \\
\text { vironmental }(25 \mathrm{c}) \text { resources }\end{array}$ \\
\hline
\end{tabular}

\subsection{Evolution of Eco-Innovative Methods applying TRIZ}

Since 2000 the Theory of Inventive Problem Solving TRIZ has been applied for development of cleaner and eco-friendly production processes with less material and energy losses, as presented in several reviews [49, 50, 51]. Table 9 summarises and chronologically sets out, with comments 66 selected eco-innovation methods using TRIZ elements or adaptions published between 2000 and 2018. Interestingly, the number of papers discussing TRIZ application for eco-innovation in the last 9 years (42 papers, in the years 2010-2018) has almost doubled in comparison with the previous decade with 24 papers in the years $2000-2009$. 
In general, TRIZ is considered as supporting ideation and creativity component of eco-innovation. A comparison of 28 of Eco-Design Methods and Tools given in [52] attests TRIZ the average level of complexity and time expenditures for its application but outlines no built-in life cycle perspective in TRIZ. At the same time a systematic literature review of existing practices on sustainability-oriented innovation (SOI) in Small and Medium Enterprises (SMEs) published in 2014 doesn't contain any references to TRIZ [53]. However, systematic eco-innovation support in SMEs with TRIZ is reported since $2011[54,55,56]$. The classical TRIZ contradiction matrix 39x39, which dates back to the extensive research of Altshuller and his co-workers in the 1970s [4], is the most frequently used and inspiring TRIZ tool in eco-ideation methods, followed by direct application of 40 inventive principles, evolution laws, effect databases. Numerous methods apply adapted or modified particular TRIZ elements or propose new tools based on the TRIZ basic concepts, such as ideality, multiscreen analysis etc. As an example of a successful TRIZ adaptation and consequent further development, one should mention the system of eco-innovation guidelines including more than 330 operators for problem definition and ideation $[56,57,58]$.

At first sight, one can assume that the ideation potential of TRIZ has been tested and fully applied in eco-design. However, a closer observation of the TRIZ-based eco-innovation methods brings to light that on the whole the application of TRIZ still remains rather fragmented and undervalued within the research community and industry. For example, the analytical TRIZ tools for problem definition and identification of engineering contradictions such as Root-Conflict Analysis, Cause-Effect-Chain-Analysis, or Function Analysis [7, 9] seem to be not applied in eco-design. No significant progress has been reported regarding application of the function-oriented search (FOS) and data mining approaches in eco-innovation. The high efficiency of the Anticipatory Failure Identification [7,59] for prevention of breakdowns and failures in new technologies and equipment is also underestimated. Even the inventive operators for solving ecoengineering contradictions are not systematically extracted or available for all application fields.

Table 9. Evolution of the eco-innovation methods applying TRIZ in 2000-2018.

\begin{tabular}{|c|c|}
\hline Reference & TRIZ integration or adaptation in eco-innovation method \\
\hline $\begin{array}{l}\text { 1. Jones and Harrison, } \\
2000[49]\end{array}$ & $\begin{array}{l}\text { Linking the headlines of } 6 \text { Eco-compass categories with } 39 \text { engi- } \\
\text { neering parameters from classical TRIZ contradiction matrix. }\end{array}$ \\
\hline $\begin{array}{l}\text { 2. Low et al., } 2000[50] \text {, } \\
2001[60]\end{array}$ & $\begin{array}{l}\text { Assigns } 9 \text { parameters of } 39 \times 39 \text { contradiction matrix to } 4 \text { general } \\
\text { environmental parameters of eco-service design. }\end{array}$ \\
\hline 3. Mann et al, 2001 [61] & $\begin{array}{l}\text { Application of evolution trends, } 40 \text { inventive principles and } \\
\text { Altshuller matrix } 39 \times 39 \text {. }\end{array}$ \\
\hline $\begin{array}{l}\text { 4. Chen and Liu, } 2001 \\
\text { [62], [63] }\end{array}$ & $\begin{array}{l}\text { Proposes a } 39 \times 7 \text { matrix containing } 39 \text { TRIZ engineering parame- } \\
\text { ters and } 7 \text { eco-efficiency elements; link to a green QFD [64]. }\end{array}$ \\
\hline 5. Chen, 2002 [12] & Ideality laws for green innovative design of products. \\
\hline $\begin{array}{l}\text { 6. Chen and Liu, } 2003 \\
{[64]}\end{array}$ & $\begin{array}{l}\text { Matrix containing } 39 \text { TRIZ engineering parameters and } 7 \text { eco-ef- } \\
\text { ficiency elements with a link to a green QFD [64]. }\end{array}$ \\
\hline $\begin{array}{l}\text { 7. Wimmer et al., } 2002 \\
{[31]}\end{array}$ & $\begin{array}{l}\text { Application of classical TRIZ elements (Inventive principles, } \\
\text { Physical effects) in ideation phase of the Eco-Design Pilot. }\end{array}$ \\
\hline
\end{tabular}


8. Chang and Chen, 2003 [65]

9. Chang and Chen, 2003 [66]

10. Strasser and Wimmer, 2003 [67]

11. Jones, 2003 [68]

12. Serban et al., 2004 [69]

13. Chang, 2004 [70]

14. Chang and Chen, 2005 [71]

15. Yen and Chen, 2005 [72]

16. Kobayashi, 2005 [73]

17. Justel et al., 2006 [74]

18. Fitzgerald et al., 2006 [75]

19. Chen and Chen, 2007 [76]

20. Sakao, 2007 [77]

21. Dekoninck et al., 2007 [78]

22. Regazzoni et al., 2009 [79]

23. Fresner et al., 2010 [11]

24. Sheng and Kok-Soo, 2010 [80]

25. Fitzgerald et al., 2010 [15]

26. D'Anna and Cascini, 2011 [81]

27. Chulvi and Vidal, 2011 [82]

28. Russo et al., 2011 [83]

29. Russo et al., 2011 [54]

30. Trappey et al., 2011 $[85$
Application of TRIZ classical contradiction matrix 39x39 in a step-by-step eco-design process.

Eco-innovative product examples for 40 TRIZ inventive principles related to 7 eco-efficiency categories.

Combination of EcoDESIGN strategies and 40 TRIZ Inventive Principles. Contradiction analysis with Problem Formulator. Applies contradiction analysis, principles of Ideality, 40 inventive principles and evolution patterns for eco-ideation. Application of TRIZ inventive principles in Design for Environment. (DfE).

A software-based eco-design method contains a 39x7 matrix with 39 TRIZ engineering parameters and 7 eco-efficiency elements. A step-by-step problem definition and solving method using TRIZ Substance-Field Analysis and its transformation rules.

Combining the concept of green design with FMEA and 39x7 matrix with 39 engineering and 7 eco-efficiency parameters.

Supporting eco-innovative product design with 39x39 TRIZ contradiction matrix and 40 inventive principles.

Environmentally friendly design for disassembly using 39x39 Altshuller matrix, 40 principles, separation principles.

ENVRIZ methodology for Design for Environment adapting 39x39 Altshuller matrix and 40 inventive principles.

Proposes 39x39 Altshuller contradiction matrix, 40 inventive principles, and substance-field analysis for eco-innovation in design for disassembly.

Design method (LCA and QFD for Environment) applies TRIZ $39 \times 39$ contradiction matrix, effects database and evolution laws. Enhancing eco-ideation brainstorming with simplified TRIZ tools based on contradiction matrix and inventive principles.

Proposes 8 eco-guidelines with corresponding 19 rules based on 8 TRIZ evolution laws and Recourses Analysis.

Combining TRIZ laws of evolution with cleaner production strategies in eco-innovation.

Problem-solving guideline called TRIZEE applies 40 TRIZ inventive principle correlating with eco-efficiency elements. Identifies 62 eco-contradictions in 80 patents and 50 products with $21 \times 6$ innovation matrix with 6 eco-goals and 21 functional eco-parameters. 39x39 contradiction matrix, 40 inventive principles.

Proposes easy-to-use SUSTAINability Map tool, based on Evolution Laws of Engineering Systems and System Operator.

Analysis of relationship between 31 evolution trends known in TRIZ and eco-design strategies of LiDS Wheel.

Offers eco-guidelines based on 8 TRIZ evolution laws and TRIZ concepts of Resources, Ideality and Ideal Final Result. 330 eco-guidelines extracted from the TRIZ laws of evolution within the European project "Recycling and Resource Efficiency driving innovation in European Manufacturing SMEs.

Combing LCA, QFDE, back-propagation network BPN for new eco-innovation, supported by TRIZ inventive principles. 
31. Yang and Chen, 2011 Combining Case-based Reasoning (CBR) and TRIZ: 39x7 matrix [86] with 7 eco-efficiency elements, 40 inventive principles, 8 evolu-

32. Tsai et al., 2011 [87] Eco-design framework adopting classical TRIZ tools: 40 inventive principles, inventive standards, evolution trends, ARIZ.

33. Yang and Chen, 2012 Combining TRIZ evolution laws with CBR, simple LCA and Ex[88]

34. Ferrer et al., 2012 [10] pert systems.

5. Russo and Birolini, 2012 [89]

36. Negny et al., 2012 [90] Eco-design tool supports resolving technical or physical contradictions with TRIZ inventive principles and Su-Field Analysis Over 300 eco-guidelines in several subsets, adopted from TRIZ laws of evolution and inventive principles.

Method based on CBR and TRIZ applies physical, chemical, biological, geometrical effects and the resources-oriented search.

37. Durieux and Teulon, Eco-ideation using TRIZ contradiction matrix and inventive prin2012 [91]

38. Hosseinpour and Peng, 2012 [92]

39. Mogensen and Rousse, 2012 [93]

40. Kallel et al., 2013 [94] ciples for improvement.

Sustainable design method using integration of Function Impact Matrix with Eco-checklist and TRIZ tools.

Use of TRIZ tools for solving contradictions (inventive principles) on material, component and system levels.

TRIZ contradiction matrix, Separation principles, Standard solutions used for problem solving and concept creation.

41. Tyl et al., 2013 [36] Application of ASIT (simplified TRIZ) creativity principles adapted for ideation phase of eco-innovation processes.

42. Cherifi et al., 2014 Linking 5 eco-efficiency parameters to 39 engineering parame[95]

43. Russo et al., 2014 [58] ters of contradiction matrix; 40 inventive principles for ideation. TRIZ-based eco-design matrix, "i-Tree" method for eco-design purposes and simplified for non-expert users.

44. Chen and Chen, 2014 Integration of Biomimetic Design and ARIZ. [96]

45. Ben Moussa et al., 2014 [97]

Confirms applicability of TRIZ tools for the problem definition and solving in the field of green logistics

46. Russo and Serafini, 2015 [3]

47. Russo et al., 2015 [56]

48. Pokhrel et al., 2015 [14]

49. Vidal et al., 2015 [98]

50. Cluzel et al., 2016 [99]

Identification of eco-engineering contradictions with the proposed Contradiction Prompter method.

Framework of eco-guidelines with 330 TRIZ-based actions or operators for problem definition and ideation.

Adapts TRIZ 39x39 contradiction matrix to a $14 \times 14$ matrix with 3 eco-engineering parameters and 8 solution principles.

Linking TRIZ evolution trends and Eco-Design Strategy Wheel: proposal of 17 trends that potentially can impact eco-design.

Recommends the application of simplified TRIZ inventive principles (e.g. known in ASIT) to support LiDS Wheel.

51. Ko et al., 2016 [100] Eco-contradiction matrix between customer needs and eco-efficiency elements; recommending TRIZ inventive principles.

52. Fayemi et al., 2016 Definition and combing of partial Idealities from different fields [101]

53. Ameknassi et al., 2016 [102]

54. Ben Moussa et al., 2017 [103]

55. Russo et al., 2017 [84]

of expertise. TRIZ inventive and separation principles.

Defines Eco-TRIZ for problem modeling and solving using 5 rules of Substance-Field-Analysis and 76 Standards solutions. Analysis of applicability of the inventive algorithm ARIZ85 for solving Green Supply Chain problems.

Eco-innovative technique "IFR index", for selecting the main LCA criticalities, adopted from TRIZ Concept of Ideal Final Result and using a set of eco-guidelines. 
56. Chen and Hung, 2017 [104]

57. Feniser et al., 2017 [55]

58. Russo et al., 2017 [84]

Linking TRIZ inventive principles to biological cases for lowcarbon eco-innovation strategy.

TRIZ integration in eco-innovation. Recommends laws of technical evolution, TRIZ inventive principles with eco-examples. Eco-innovative technique "IFR index", for selecting the main LCA criticalities, adopted from TRIZ Concept of Ideal Final Result and using a set of eco-guidelines,

59. Bersano et al., 2017 Eco-design methodology based on abridged Life Cycle Assess[105] ment (aLCA) tools and more than 300 TRIZ-related eco guidelines

60. Caligiana et al., 2017 Application of TRIZ and QFD for sustainable eco-friendly design [106] process

61. Maccioni et al., 2017 Analysis of ideation stimuli for sustainable design clustered in [57] TRIZ ideality categories: useful functions, attenuation of undesired effects, reduction of consumed resources.

62. Russo et al., 2017 [107]

Framework to build guidelines for eco-improvements, balancing the completeness and simplicity of eco-innovations tools, such as e.g. TRIZ based eco-guidelines.

63. Chen, 2018 [108] Kansei ECO TRIZ model using 39x39 Altshuller matrix and 40 inventive principles

64. Livotov et al., 2018 Updated 40 TRIZ principles with 160 sub-principles for eco[109] problems in process engineering

\section{TRIZ Inventive Principles for Resolving Eco-Contradictions}

The analysis of 100 eco-patents (Fig. 4), 58 thermal operations and methods (Fig. 5), 144 eco-engineering contradictions in the Altshuller matrix (Fig. 6), and of the reviewed eco-innovation methods allows one to select the strongest TRIZ inventive principles for environmental problems in process engineering. The mean occurrence frequency of principles in 100 eco-patents and 58 thermal operations has been determined as a ranking metric and resulted in the following selection of top 15 principles presented in Table 10 .

Additionally, the evaluated partial ranking of the sub-principles detects the statistically strongest inventive operators. The major benefit of applying strongest sub-principles can be characterized by the time-saving, more efficient and precise ideation. For example, the top 15 principles contain 61 sub-principles which should be applied by the engineers for problem solving. Among 61 sub-principles only 23 have a ranking higher than 0,01 . Thus, the ideation activities can be focused on these strongest $23 \mathrm{sub}-$ principles. The new enhanced version of 40 TRIZ principles with 160 sub-principles (2018), used in the analysis, is presented in the Appendix. 
Table 10. Selection of TRIZ inventive principles for solving eco-contradictions.

\begin{tabular}{|c|c|c|c|}
\hline Pos. & Inventive principle & $\begin{array}{l}\text { Rank- } \\
\text { ing }\end{array}$ & $\begin{array}{c}\text { Corresponding sub-principles } \\
\text { with their partial ranking }\end{array}$ \\
\hline 1 & 35 Transform physical and chemical properties & 0,099 & $\begin{array}{l}\text { 35a:0.033, 35b:0.028, 35d:0.034, 35e: } \\
0.004 .\end{array}$ \\
\hline 2 & 02 Leaving out / Trimming & 0,099 & 2a:0.053, 2b:0.003, 2c:0.007, 2e:0.036. \\
\hline 3 & 05 Combining & 0,079 & 5a:0.030, 5b:0.034, 5c:0.01, 5d:0.005. \\
\hline 4 & 25 Self-service / Use of resources & 0,076 & 25a:0.026, 25b:0.041, 25c:0.009. \\
\hline 5 & 29 Pneumatic or hydraulic constructions & 0,073 & 29a:0,017, 29c:0.004, 29e: 0.052. \\
\hline 6 & 28 Replace mechanical working principle & 0,041 & 28a:0.032, 28c:0.009. \\
\hline 7 & 15 Dynamism and adaptability & 0,038 & 15a: $0.023,15 \mathrm{~b}: 0.011,15 \mathrm{c}: 0.004$. \\
\hline 8 & 22 Converting harm into benefit & 0,034 & 22a: 0.034 \\
\hline 9 & 10 Prior useful action & 0,034 & 10a: 0.034 \\
\hline 10 & 09 Prior Counteraction of harm & 0,031 & 9a: $0.013,9 \mathrm{~b}: 0.013,9 \mathrm{~d}: 0.005$. \\
\hline 11 & 01 Segmentation & 0,029 & $\begin{array}{l}\text { 1a:0.013, 1b:0.005, 1c:0.004, 1d:0.004, } \\
\text { 1e:0.003. }\end{array}$ \\
\hline 12 & 34 Rejecting and regenerating parts & 0,029 & 34a:0.025, 34b:0.004. \\
\hline 13 & 36 Phase transitions & 0,028 & 36a:0.028 \\
\hline 14 & 20 Continuity of useful action & 0,025 & 20a:0.025 \\
\hline 15 & 40 Composite materials & 0,024 & 40a:0.015, 40c:0.009 \\
\hline (16) & 24 Mediator & 0,022 & 24a: $0.012,24 \mathrm{~b}: 0.010$ \\
\hline (17) & 03 Local quality & 0,014 & 3a:0.011, 3b:0.003. \\
\hline (18) & 17 Shift to another dimension & 0,010 & 17c: $0.005,17 \mathrm{e}: 0.005$ \\
\hline (19) & 18 Mechanical vibration & 0,009 & 18a:0.003, 18e: 0.006 \\
\hline$(20)$ & 19 Periodic action & 0,003 & 19a: 0.003 \\
\hline
\end{tabular}

Taking into consideration the evaluation of eco-contradictions in the Altshuller matrix and several literature sources five additional principles (Pos. 16-20 in Table 10) with lower ranking can be added to the list.

As shown in Table 11, TRIZ Inventive Principles can be grouped and displayed in the recommended order of application [110]. Generally, one starts with the 12 statistically strongest principles (Group 1), followed either by the principles for design problems (Group 2) or by the principles for specific problems in process engineering (Group 3 ). Characteristically, the identified 15 strongest inventive principles for eco-engineering problems, indicated in Table 11 in bold and italics, are distributed almost evenly 
over three groups. Moreover, six of them are identical with the statistically strongest inventive principles NN 35, 10, 1, 28, 2, 15.

Table 11. Groups of 40 TRIZ inventive principles with the highlighted strongest 15 inventive principles for eco-engineering problems (in bold and italics).

\begin{tabular}{|c|c|c|}
\hline $\begin{array}{l}\text { Group 1: } \\
12 \text { statistically strongest in- } \\
\text { ventive principles }\end{array}$ & $\begin{array}{l}\text { Group 2: } \\
13 \text { principles for solving de- } \\
\text { sign problems }\end{array}$ & $\begin{array}{l}\text { Group 3: } \\
15 \text { principles for specific } \\
\text { problems in process engi- } \\
\text { neering }\end{array}$ \\
\hline $\begin{array}{l}\text { 35. Transformation of } \\
\text { physical and chemical } \\
\text { properties } \\
\text { 10. Prior useful action } \\
\text { 1. Segmentation } \\
\text { 28. Replace mechanical } \\
\text { working principle } \\
\text { 2. Leaving out/Trimming } \\
\text { 15. Dynamism and adapta- } \\
\text { bility } \\
\text { 19. Periodic action } \\
\text { 3. Local quality } \\
\text { 17. Shift to another dimen- } \\
\text { sion } \\
\text { 13. Inversion } \\
\text { 18. Mechanical vibration } \\
\text { 26. Copying and Modeling }\end{array}$ & $\begin{array}{l}\text { 6. Universality } \\
\text { 5. Combining } \\
\text { 29. Pneumatic or hydraulic } \\
\text { constructions } \\
\text { 30. Flexible shells or thin } \\
\text { films } \\
\text { 7. Nesting / Integration } \\
\text { 8. Anti-weight } \\
\text { 4. Asymmetry } \\
\text { 40. Composite materials } \\
\text { 24. Mediator } \\
\text { 14. Sphericity and Rotation } \\
\text { 23. Feedback and automa- } \\
\text { tion } \\
\text { 31. Porous materials } \\
\text { 25. Self-service / Use of re- } \\
\text { sources }\end{array}$ & $\begin{array}{l}\text { 16. Partial or excessive ac- } \\
\text { tion } \\
\text { 27. Disposability / Cheap } \\
\text { short living objects } \\
\text { 20. Continuity of useful ac- } \\
\text { tion 32. Change colour } \\
\text { 21. Skipping / Rushing } \\
\text { through } \\
\text { 11. Preventive measure / } \\
\text { Cushion in advance } \\
\text { 33. Homogeneity } \\
\text { 22. Converting harm into } \\
\text { benefit } \\
\text { 39. Inert environment } \\
\text { 37. Thermal expansion } \\
\text { 36. Phase transitions } \\
\text { 38. Strong oxidants } \\
\text { 34. Rejecting and regener- } \\
\text { ating parts } \\
\text { 12. Equipotentiality } \\
\text { 9. Prior counteraction of } \\
\text { harm }\end{array}$ \\
\hline
\end{tabular}

\section{$5 \quad$ Concluding Remarks and Outlook}

The objective of the presented research was to reveal primary and secondary ecoproblems in process engineering and especially in the field of intensification of processes involving solids handling. The performed full-text analysis of 100 patent documents dealing with eco-problems resulted in the identification of large amount of secondary eco-contradictions, characterized by the situation at which solving of the primary eco-problem causes an additional ecological negative effect. It was shown that high energy consumption or losses, air pollution and acidification belong to the major negative side effects in eco-contradictions.

Secondary eco-contradictions can be documented and predicted with the help of correlation matrices of dynamically variable format, starting with $14 \times 14$ environmental categories as input parameters. The future analysis should clarify how adjustment of matrix resolution can improve the accuracy of contradiction identification. Also, the 
patent analysis can be partially or completely automated by means of data mining and processing, in order to reduce the currently high time expenditures for identification of invention goals, secondary problems and their correlations.

Additionally, a set of top 15 TRIZ inventive principles most frequently used in inventions dealing with eco-problems was extracted from the patent literature and PI technologies. It can be generally suggested for the practical use not only in process engineering. A future analysis should validate and refine given recommendations.

Since the implementation of eco-friendly solutions often causes secondary problems, TRIZ methodology can limit these negative side effects. The review of more than 60 eco-design approaches and methods using TRIZ confirms this statement. The TRIZ principles of Ideality, Resource-oriented and compromise-free problem solving fit in perfectly with the strategy of sustainable eco-innovation. On the one hand, the application of the TRIZ-based approaches helps to identify secondary problems, to predict and creatively solve eco-contradictions in advance. And on the other hand, TRIZ helps to mobilize resources of the existing processes and to reduce the negative environmental impact of technologies without efficiency losses. The authors advocate the approach of a comprehensive adaptable TRIZ-based toolbox and intuitively-to-use best-practice recommendations for its seamless integration into existing Eco-Design and Eco-Innovation framework, not only in the field of process engineering.

Acknowledgments. The authors thank the European Commission for supporting their work as part of the research project - "Intensified by Design (IbD) - Platform for the intensification of processes involving solids handling" under HORIZON 2020 SPIRE programme (SPIRE-08-2015-680565).

This publication is a revised and extended version of the paper "Environmental Problems and Inventive Solution Principles in Process Engineering" [109] presented at the $18^{\text {th }}$ International TRIZ Future Conference "Towards automated inventions for smart industries" in Strasbourg, October 2018.

Appendix. TRIZ Inventive Principles with 160 sup-principles for Process Engineering adapted from [23] without description and examples.

1. Segmentation: 1(a) Segment object; 1(b) Dismountable design; 1(c) Segment to microlevel; 1(d) Segment function; 1(e) Segment process.

2. Leaving out / Trimming: 2(a) Take out disturbing parts; 2(b) Trim components; 2(c) Trim functions; 2(d) Trim process steps; 2(e) Extract useful element.

3. Local quality: 3(a) Non-uniform object; 3(b) Non-uniform environment; 3(c) Different functions; 3(d) Optimal conditions; 3(e) Opposite properties.

4. Asymmetry: 4(a) Asymmetry; 4(b) Enhance asymmetry; 4(c) Back to symmetry.

5. Combining; 5(a) Combine similar objects; 5(b) Combine functions; 5(c) Combine different properties; 5(d) Combine complementary properties; 5(e) Combine opposing properties.

6. Universality: 6(a) Universal object; 6(b) Universal process.

7. Nesting / Integration: 7(a) Nested objects; 7(b) Passing through cavities; 7(c) Telescopic systems. 
8. Anti-weight: 8(a) Use counterweight; 8(b) Buoyancy; 8(c) Aero- or hydrodynamics; 8(d) Use gravitational or centrifugal forces.

9. Prior Counteraction of harm: 9(a) Counter harm in advance; 9(b) Anti-stress; 9(c) Cooling in advance; 9(d) Rigid construction.

10. Prior useful action: 10(a) Prior useful function; 10(b) Pre-arrange objects; 10(c) Prior process step.

11. Preventive measure / Cushion in advance: 11(a) Safety cushion; 11(b) Preventive measures.

12. Equipotentiality: 12(a) Keep altitude; 12(b) Equipotentiality; 12(c) Avoid fluctuations.

13. Inversion: 13(a) Inversed action; 13(b) Make fixed parts to movable; 13(c) Upside down; 13(d) Reversed sequence; 13(e) Invert environment.

14. Sphericity and Rotation: 14(a) Ball-shaped forms; 14(b) Spheres and cylinders; 14(c) Rotary motion; 14(d) Swirling motion; 14(e) Centrifugal forces.

15. Dynamism and adaptability: 15(a) Optimal performance; 15(b) Adaptive object; 15(c) Adaptive process; 15(d) Flexible elements; 15(e) Change statics to dynamics

16. Partial or excessive action: 16(a) One step back from ideal; 16(b) Optimal substance amount; 16(c) Optimal action.

17. Shift to another dimension: 17(a) Multi-dimensional form; 17(b) Miniaturization; 17(c) Multi-layered structure; 17(d) Tilt object; 17(e) 3D interaction.

18. Mechanical vibration: 18(a) Oscillate object; 18(b) Ultrasound; 18(c) Resonance; 18(d) Piezo-electric vibrators; 18(e) Ultrasound with other fields.

19. Periodic action: 19(a) Periodic action; 19(b) Change frequency; 19(c) Use pauses; 19(d) Match frequencies; 19(e) Separate in time.

20. Continuity of useful action: 20(a) Continuous process; 20(b) Operate at full load; 20(c) Eliminate idle work.

21. Skipping / Rushing through: 21(a) Skip hazardous operations; 21(b) Boost the process.

22. Converting harm into benefit: 22(a) Utilize harm; 22(b) Remove harm with harm; 22(c) Amplify harm to avoid it.

23. Feedback and automation: 23(a) Introduce feedback; 23(b) Enhance feedback; 23(c) Automation; 23(d) Data processing.

24. Mediator: 24(a) Intermediate object; 24(b) Temporary mediator; 24(c) Intermediary process.

25. Self-service / Use of resources: 25(a) Object serves itself; 25(b) Utilize waste resources; 25(c) Use environmental resources.

26. Copying: 26(a) Simple copies; 26(b) Optical copies; 26(c) Invisible copies; 26(d) Digital models; 26(e) Virtual reality.

27. Disposability / cheap short-living objects: 27(a) Short-living objects; 27(b) Multiple cheap objects; 27(c) One-way objects; 27(d) Create objects from resources.

28. Replace mechanical working principle: 28(a) Use electromagnetics; 28(b) Optical systems; 28(c) Acoustic system; 28(d) Chemical and biosystems; 28(e) Magnetic particles and fluids. 
29. Pneumatic or hydraulic constructions: 29(a) Gaseous or liquid flows; 29(b) Gas or liquid under pressure; 29(c) Use vacuum; 29(d) Fluidization; 29(e) Heat transfer and exchange.

30. Flexible shells or thin films: 30(a) Flexible shells or films; 30(b) Flexible isolation; 30(c) Piezoelectric foils; 30(d) Use rushes; 30(e) Use membranes.

31. Porous material: 31(a) Add porous elements; 31(b) Fill pores with substance; 31(c) Use capillary effects; 31(d) Physical effects and porosity; 31(e) Structured porosity.

32. Change colour: 32(a) Change colour; 32(b) Change transparency; 32(c) Coloured additives; 32(d) Use tracer.

33. Homogeneity: 33(a) Similar materials; 33(b) Similar properties; 33(c) Uniform properties.

34. Rejecting and regenerating parts: 34(a) Discard useless parts; 34(b) Restore parts; 34 (c) Create parts on time and on site.

35. Transform physical and chemical properties: 35(a) Change aggregate state; 35(b) Change concentration; 35(c) Change physical properties; 35(d) Change temperature; 35(e) Change chemical properties.

36. Phase transitions: 36(a) Phase transitions; 36(b) 2nd order phase transitions

37. Thermal expansion: 37(a) Thermal expansion; 37(b) Bi-metals; 37(c) Heat shrinking; 37(d) Shape memory.

38. Strong Oxidants: 38(a) Oxygen-enriched air; 38(b) Use pure oxygen; 38(c) Use ionized oxygen; 38(d) Use ozone; 38(e) Strong oxidants.

39. Inert environment: 39(a) Inert environment; 39(b) Inert atmosphere process; 39(c) Process in vacuum; 39(d) Inert coatings or additives; 39(e) Use foams.

40. Composite materials: 40(a) Composite materials; 40(b) Use anisotropic properties; 40(c) Additives in composites; 40(d) Composite microstructure; 40(e) Combine different aggregate states.

\section{References}

1. D. Casner, P. Livotov, Mas'udah, P.K. da Silva, TRIZ-based approach for process intensification and problem solving in process engineering: concepts and research agenda, In: Koziołek, S.; Chechurin, L.; Collan, M. (eds). Advances and Impacts of the Theory of Inventive Problem Solving. The TRIZ Methodology, Tools and Case Studies, Springer, 2018, ISBN 978-3-319-96531-4, in print.

2. F. Calza, A. Parmentola, I. Tutore, Types of Green Innovations: Ways of Implementation in a Non-Green Industry. Sustainability 2017, 9, 1301; doi:10.3390/su9081301.

3. D. Russo, M. Serafini, Anticipating the Identification of Contradictions in Eco-design Problems. Procedia Engineering 131 (2015) 1011-1020.

4. G.S. Altshuller, Creativity as an Exact Science, The Theory of the Solution of Inventive Problems, Gordon \& Breach Science Publishers, ISSN 0275-5807 (1984).

5. P. Livotov, Sustainable European Collaboration in the Field of Knowledge-Based Innovation and Inventive Problem Solving with TRIZ, Journal of the European TRIZ Association 01/2017 (03), pp. 1-3, ISSN 1866-4180, http://www.etria.eu/portal/index.php/conferencepapers-and-proceedings/126-etria-journal-01-2017-03. 
6. D. Cavallucci, G. Cascini, J. Duflou, et al., TRIZ and Knowledge-Based Innovation in Science and Industry, Procedia Engineering 131 (2015) 1-2, doi:10.1016/j.proeng. 2015.12.341.

7. VDI Standard 4521, Inventive problem solving with TRIZ, Fundamentals, terms and definitions, The Association of German Engineers (VDI), Beuth, Duesseldorf, (2016).

8. D. Cavallucci, F. Rousselot, et al., Initial situation analysis through problem graph, CIRP J. Manuf. Sci. Technol. 2, (2010) 310-317. doi:10.1016/j.cirpj.2010.07.004.

9. P. Livotov, D. Casner, R. Houssin, J. Renaud, Problem definition and identification of contradictions in the interdisciplinary areas of mechatronic engineering, In: Koziołek, S.; Chechurin, L.; Collan, M. (eds), Advances and Impacts of the Theory of Inventive Problem Solving, The TRIZ Methodology, Tools and Case Studies, Springer, 2018, ISBN 978-3-31996531-4, in print.

10. J.B. Ferrer, S. Negny, G.C. Robles, J.M. Le Lann, Eco-innovative design method for process engineering, Computers \& Chemical Engineering vol. 45 (2012) 137-151.

11. J. Fresner, J. Jantschgi, S. Birkel, J. Barnthaler, C. Krenn, The theory of inventive problem solving (TRIZ) as option generation tool within cleaner production projects, Journal of Cleaner Production 18 (2) (2010) 128-136.

12. J. L. Chen, Green evolution rules and ideality laws for green innovative design of products. Fourth international symposium on going Green-care innovation, (2002) 130-134.

13. D. Russo, M. Serafini, C. Rizzi, Is TRIZ an Eco-Design Method? In: Setchi, R., Howlett, R.J., Liu, Y. and Theobald, P. (eds.) Sustainable Design and Manufacturing, Springer, (2016) 525-536.

14. C. Pokhrel, C. Cruz, Y. Ramirez, A. Kraslawski, Adaptation of TRIZ contradiction matrix for solving problems in process engineering, Chemical Engineering Research and Design, Volume 103 (2015) 3-10.

15. D.-P. Fitzgerald, J.-W. Herrmann, L.-C. Schmidt, A Conceptual Design Tool for Resolving Conflicts between Product Functionality and Environmental Impact, Journal of Mechanical Design 132(9), 2010, doi:10.1115/1.4002144.

16. N. Bocken, J. Allwood, A. Willey, J. King, Development of an eco-ideation tool to identify stepwise greenhouse gas emissions reduction options for consumer goods, Journal of Cleaner Production vol. 19, no.12, (2011) pp. 1279-1287, https://doi.org/10.1016/j.jclepro.2011.04.009.

17. Intensified by Design (IbD) - Platform for the intensification of processes involving solids handling, EU Research Project (Horizon 2020, SPIRE Programme), http://ibd-project.eu/ (accessed 14.09.2018).

18. G. Cascini, D. Russo, Computer-aided analysis of patents and search for TRIZ contradictions, Int. J. Product Development vol. 4, nos. 1/2, (2007) pp. 52-67.

19. P. Livotov, Mas'udah, A. Sarsenova, A.P. Chandra Sekaran, Identification of secondary problems of new technologies in process engineering by patent analysis, Leonid Chechurin and Mikael Collan (Eds): Advances in Systematic Creativity, Springer Nature 2018, 978-3319-78074-0, in print.

20. G. Asche, " $80 \%$ of technical information found only in patents" - Is there proof of this? World Patent Information, Volume 48, (2017) Pages 16-28. https://doi.org/10.1016/j.wpi.2016.11.004.

21. C. Azzaro-Pantel, Green Process Engineering Design Methodology: A Multicriteria Approach, In: Poux, M., Cognet, P., Gourdon, C. (Eds): Green Process Engineering: From Concepts to Industrial Applications, CRC Press, 2015, pages 3-26, ISBN 9781482208177. 
22. D. Casner, P. Livotov, Advanced innovation design approach for process engineering, Proceedings of the 21st Int. Conf. on Engineering Design (ICED 17), Vol 4: Design Methods and Tools, Vancouver, (2017) pp. 653-662.

23. P. Livotov, A.P. Chandra Sekaran, R. Law, Mas'udah, D.A Reay, Systematic Innovation in Process Engineering: Linking TRIZ and Process Intensification. Leonid Chechurin and Mikael Collan (Eds): Advances in Systematic Creativity, Springer Nature 2018, 978-3-31978074-0, in print.

24. P. Livotov, Contradiction Matrix. In Livotov, P., Petrov, V.: TRIZ Innovation Technology, Product Development and Inventive Problem Solving, Handbook. Berlin, TriS Europe, 2011, 284 p., pp 237-246. https://www.researchgate.net/publication/327248413_Chapter 14 Resolving Contradictions using the Contradiction Matrix

25. J. R. McDonough, R. Law, D. Reay, V. Zivkovic, Intensified carbon capture using adsorption: Heat transfer challenges and potential solutions, Thermal Science and Engineering Progress, Volume 8, December 2018, Pages 17-30, https://doi.org/10.1016/j.tsep.2018.07.012

26. D.L. Mann, S. Dewulf, B. Zlotin, A. Zusman, Matrix 2003: Updating the TRIZ Contradiction Matrix', CREAX Press, February 2003.

27. V. Oltra, M. Saint Jean, Sectoral systems of environmental innovation: An application to the French automotive industry, Technol. Forecast. Soc. Chang. 76 (2009) 567-583.

28. C. Fussler, P. James, Driving Eco-Innovation: a breakthrough discipline for innovation and sustainability, Pitman Publishing, London, (1996).

29. H. Brezet, C. van Hemel, Ecodesign: A Promising Approach to Sustainable Production \& Consumption, UNEP, Paris, ISBN 928071631X, 346 p. (1997).

30. P. James, The sustainability cycle: a new tool for product development and design, Journal of Sustainable Product Design, Issue No. 2, July 1997, (1997) pp. 52-57.

31. W. Wimmer, R. Züst, Ch. Strasser, The Application of the ECODESIGN PILOT and Methodical Support for the Implementation of ECODESIGN in Products, In: Proceedings of the 7th International Design Conference, Dubrovnik, Design Society, (2002) pp. 1357-1364.

32. N. Bocken, S. Short, P. Rana, S. Evans, A value mapping tool for sustainable business modelling, Corporate Governance: The International Journal of Business in Society, Vol. 13 No. 5, (2013) pp. 482-497, https://doi.org/10.1108/CG-06-2013-0078.

33. D. P. Fitzgerald, J. W. Herrmann, P. A. Sandborn, L. C. Schmidt, T. H. Gogoll, "Design for Environment (DfE): Strategies, Practices, Guidelines, Methods, and Tools," Environmentally Conscious Mechanical Design, M. Kutz, ed., Wiley, Hoboken, NJ., (2007).

34. K. Masui, Quality function deployment for environment: QFDE - a methodology in early stage of DfE, In: Proceedings of Second International Symposium on Environmentally Conscious Design and Inverse Manufacturing, IEEE, Japan, (2001) pp. 852-857.

35. E.R. Wolniak, A. Sedek, Using QFD Method for the Ecological Designing of Products and Services, Quality and Quantity 43 (4) (2008) 695-701.

36. B. Tyl, J. Legardeur, D. Millet, F. Vallet, Adaptation of the Creativity Tool ASIT to Support Eco-Ideation Phases, In: Telma Ferreira (ed.): Green Design, Materials and Manufacturing Processes, Leiden: CRC Press/Balkema (2013) 437-442.

37. B. Tyl, J. Legardeur, D. Millet, F. Vallet, A comparative study of ideation mechanisms used in eco-innovation tools, Journal of Engineering Design, Vol. 25, No. 10-12, (2014) pp. 325345. https://doi.org/10.1080/09544828.2014.992772.

38. P. T. Anastas, L. Heine, T. C. Williamson (Eds), Green Engineering, American Chemical Society: Washington, DC, 2000.

39. P.T. Anastas, J.B. and Zimmerman, Design through the Twelve Principles of Green Engineering, Environmental Science \& Technology, March 1, (2003) 94A-101A, DOI: $10.1021 /$ es032373g. 
40. B. Tyl, F. Vallet, O. Pialot, D. Millet, J. Le Duigou, G. Graves, The ESM approach: 8 mechanisms to efficiently support eco-ideation, Proceedings of the DESIGN 2016/14th International Design Conference, Dubrovnik, Croatia, May 16-19, 2016, The Design Society, Glasgow, (2016).

41. Martine Poux, Patrick Cognet, Christophe Gourdon (Eds). Green Process Engineering: From Concepts to Industrial Applications. CRC Press, 2015, 470 pages, ISBN 9781482208177.

42. K.V.K Boodhoo, A. Harvey, Process intensification: an overview of principles and practice, in: K.V.K. Boodhoo, A. Harvey (Eds.), Process Intensification for Green Chemistry: Engineering Solutions for Sustainable Chemical Processing, John Wiley, Sons, (2013) 1-31.

43. A.I. Stankiewicz, J.A. Moulijn, Process intensification: transforming chemical engineering, Chem. Eng. Prog. (2000) 96:22-34.

44. W. Cross, C. Ramshaw, Process intensification: laminar flow heat transfer, Chem. Eng. Res. Des. (1986) 64:293-301.

45. D. Reay, C. Ramshaw, A. Harvey, Process Intensification: Engineering for Efficiency, Sustainability, and Flexibility. 2nd ed., Butterworth-Heinemann, Oxford, (2013).

46. H. Wang, A. Mustaffar, A.N. Phan, V. Zivkovic, D. Reay, R. Law, K. Boodhoo, A review of process intensification applied to solids handling, Chemical Engineering and Processing: Process Intensification, 118 (2017) pp 78-107, https://www.sciencedirect.com/science/article/pii/S0255270116306742.

47. R. Law, C. Ramshaw, D. Reay, Process intensification - overcoming impediments to heat and mass transfer enhancement when solids are present, via the IbD project, Thermal Science and Engineering Progress 1 (2017) 53-58, https://www.sciencedirect.com/science/article/pii/S2451904917300112.

48. J.-M. Commenge, L. Falk, Methodological framework for choice of intensified equipment and development of innovative technologies, Chemical Engineering and Processing 84 (2014) 109-127.

49. E. Jones, D. Harrison, Investigating the use of TRIZ in Eco-innovation, In: TRIZCON2000 conference proceedings, Altshuller Institute, USA, 2000, https://triz-journal.com/investigating-use-triz-eco-innovation (accessed 10.08.2018).

50. M.K. Low, T. Lamvik, K. Walsh, O. Myklebust, Product to service eco-innovation: the TRIZ model of creativity explored, In: 2000 IEEE International Symposium on Electronics and the Environment, IEEE, USA, (2000) pp. 209-214.

51. S. Buzuku, L. Shnai, A systematic literature review of TRIZ used in Eco-Design, Journal of the European TRIZ Association, 02-2017 (04), ISSN 1866-4180, 20-31 (2017).

52. M. Lindahl, S. Ekermann, Structure for Categorization of EcoDesign Methods and Tools, In book: Andrew Y. C. Nee, Bin Song, Soh-Khim Ong (Eds) Re-engineering Manufacturing for Sustainability: Proceedings of the 20th CIRP International Conference on Life Cycle Engineering, Springer Science \& Business Media, Singapore, 17-19 April, 2013, 738 P., pp 117-122, DOI: 10.1007/978-981-4451-48-2_19.

53. J. Klewitz, E.G. Hansen, Sustainability-oriented innovation of SMEs: a systematic review, Journal of Cleaner Production 65, (2014) 57-75.

54. D. Russo, G. Bersano, V. Birolini, R. Uhl, European testing of the efficiency of TRIZ in eco-innovation projects for manufacturing SMEs, Procedia Engineering 9 (2011) 157-171.

55. C. Feniser, , G. Burz, M. Mocan, L. Ivascu, V. Gherhes, C.C. Otel, The Evaluation and Application of the TRIZ Method for Increasing Eco-Innovative Levels in SMEs, Journal of Cleaner Production 9 (7) (2017) 1-19.

56. D. Russo, M. Schöfer, G. Bersano, Supporting ECO-innovation in SMEs by TRIZ Ecoguidelines, Procedia Engineering 131 (2015) 831-839. 
57. L. Maccioni, Y. Borgianni, F. Rotini, Sustainability as a Value-Adding Concept in the Early Design Phases? Insights from Stimulated Ideation Sessions, In: Campana G., Howlett R., Setchi R., Cimatti B. (eds) Sustainable Design and Manufacturing 2017, SDM 2017, Smart Innovation, Systems and Technologies, vol 68. Springer, Cham, (2017).

58. D. Russo, C. Rizzi, G. Montelisciani, Inventive guidelines for a TRIZ-based eco-design matrix. Journal of Cleaner Production 76 (2014) 95-105.

59. P. Livotov, G. Weimar G: Thinking the unthinkable. Prevision of faults to detect possible breakdowns in equipment and plants. Das Undenkbare denken. Vorausschauende Fehlererkennung zur Ermittlung möglicher Störungen an Maschinen und Anlagen. Qualität \& Zuverlässigkeit QZ 03/2000, ISSN 0720-1214, pp. 308-312, (2000).

60. M.K. Low, T. Lamvik, K. Walsh, O. Myklebust, Manufacturing a Green Service: Engaging the TRIZ Model of Innovation, In: 2001 IEEE Transactions On Electronics Packaging Manufacturing, Vol. 24, IEEE, USA, (2001) PP: 10-17.

61. D. Mann, D. Harrison, Stanton, N.A. An Eco-innovation Case Study of Domestic Dishwashing through the Application of TRIZ Tools, Creativity and Innovation Management, Vol. 10, No.1, March 2001, pp. 3-14, DOI: 10.1111/1467-8691.00186.

62. C.C. Liu, J.L. Chen, Development of Product Green Innovation Design Method, In: Second International Symposium on Environmentally Conscious Design and Inverse Manufacturing proceedings, IEEE, Japan, (2001) pp. 168-173.

63. J.L. Chen, C.C. Liu, An eco-innovative design approach incorporating the TRIZ method without contradiction analysis, The Journal of Sustainable Product Design 1(4) (2001) 263272.

64. J.L. Chen, C.-C. Liu, An eco-innovative design method by green QFD and TRIZ tools, In: Folkeson, A., Gralen, K. (eds.) 14th International Conference on Engineering Design ICED 03 proceedings, Design Society, Sweden, (2003).

65. H.T. Chang, J.L Chen, An Eco-innovative design method based on design-around approach, In: 3rd International Symposium on Environmentally Conscious Design and Inverse Manufacturing proceedings, IEEE, Japan, (2003) pp. 575-582.

66. H.T. Chang, J.L. Chen, Eco-Innovative Examples for 40 TRIZ Inventive Principles, TRIZ Journal (2003), https://riz-journal.com/eco-innovative-examples-40-triz-inventive-principles/, (accessed 19.09.2018).

67. Ch. Strasser, W.Wimmer, Eco-innovation, combining eco-design and TRIZ for environmentally sound product development, In: 14th International Conference on Engineering Design ICED 03 proceedings, Design Society, Sweden, (2003) pp. 1-19.

68. E.Jones, Eco-innovation: Tools to Facilitate Early-Stage Workshop, PhD thesis, Brunel University, UK, (2003).

69. D. Serban, E. Man, N. Lonescu, T. Roche, A TRIZ Approach to Design for Environment, In: Talabă, D., Roche, T. (eds.) Product Engineering, LNCS, Springer, Dordrecht, (2004) pp. 89-100.

70. H.T. Chang, The conflict-problem-solving CAD software integrating TRIZ into eco-innovation, Advances in Engineering Software 35 (8-9) (2004) 553-566.

71. H.-T. Chang, J.L. Chen, The Study of Integrating Su-Field Analysis Modeling with EcoInnovative Concept for Product Design, In: 4th International Symposium on Environmentally Conscious Design and Inverse Manufacturing, IEEE, Japan, (2005) pp. 663-670.

72. S.-B. Yen, J.L. Chen, An Eco-Innovative Tool by Integrating FMEA and TRIZ Methods, In: 4th International Symposium on Environmentally Conscious Design and Inverse Manufacturing, IEEE, Japan (2005) pp. 678-683. 
73. H. Kobayashi, A systematic approach to eco-innovative product design based on life cycle planning, Advanced Engineering Informatics, Volume 20, (2006) Pages 113-125. https://doi.org/10.1016/j.aei.2005.11.002.

74. D. Justel, R. Vidal, and M. Chiner, TRIZ applied to innovate in design for disassembly, 13th CIRP International Conference on Life Cycle Engineering, vol. 31, (2006) pp. 377-382.

75. D. Fitzgerald, J. Herrmann, and L. Schmidt, Improving environmental design using TRIZ inventive principles, Proceedings of the 16th CIRP International Design Seminar, (2006).

76. J.L. Chen, W.C. Chen, TRIZ Based Eco-Innovation in Design for Active Disassembly, In: Takata S., Umeda Y. (eds) Advances in Life Cycle Engineering for Sustainable Manufacturing Businesses, Springer, London, (2007) pp. 83-87, DOI: 10.1007/978-1-84628-9354_15.

77. T. Sakao, A QFD-centred design methodology for environmentally conscious product design, International Journal of Production Research 45 (18-19) (2007) 4143-4162.

78. E. Dekoninck, D. Harrison, N.A. Stanton, New tools for the early stages of eco-innovation: an evaluation of simplified TRIZ tools, Journal of Design Research, Jan 2007, Vol. 6, Issue 1-2, (2007) pp. 122-141, doi: 10.1504/JDR.2007.015566.

79. D. Regazzoni, C. Rizzi, D. Russo, TRIZ-Driven ECO-Design and Innovation, ICORD 09: Proceedings of the 2nd International Conference on Research into Design, Bangalore, India 07.-09.01.2009, pp. 105-112.

80. I.L.S. Sheng, T. Kok-Soo, Eco-Efficient product design using Theory of Inventive Problem Solving (TRIZ) principles, American Journal of Applied Sciences 7(6), (2010) 852-858.

81. W. D'Anna, and G. Cascini, Supporting sustainable innovation through TRIZ system thinking, Procedia Engineering 9 (2011) 145-156, https://doi.org/10.1016/j.proeng.2011.03.108.

82. V. Chulvi, R. Vidal, Usefulness of evolution lines in eco-design, Procedia Engineering 9 (2011) 135-144.

83. D. Russo, D. Regazzoni, T. Montecchi, Eco-design with TRIZ laws of evolution. Procedia Engineering 9 (2011) 311-322.

84. D. Russo, C. Rizzi, P-E. Fayemi, An Industrial Application of a TRIZ Based Eco-Design Approach, In: Campana G., Howlett R., Setchi R., Cimatti B. (eds) Sustainable Design and Manufacturing 2017, SDM 2017, Smart Innovation, Systems and Technologies, vol 68. Springer, Cham, (2017), https://doi.org/10.1016/j.jclepro.2014.04.057.

85. A.J.C. Trappey, J.J.R. Ou, G.Y.P. Lin, M.-Y Chen, An eco- and inno-product design system applying integrated and intelligent QFDE and TRIZ methodology, Journal of Systems Science and Systems Engineering 20(4) (2011) 443-459.

86. C.J. Yang, J.L. Chen, Accelerating preliminary eco-innovation design for products that integrates case-based reasoning and TRIZ method, Journal of Cleaner Production 19 (9-10) (2011) 998-1006.

87. J.-P. Tsai, R.-S. Lee, M.-C. Wang, Development of Eco-Innovative Framework and Methodology for Product Design, Int. Journal of Systematic Innovation, (2011) 42-51.

88. C.J. Yang, J.L. Chen, Forecasting the design of eco-products by integrating TRIZ evolution patterns with CBR and Simple LCA methods, Expert Systems with Application 39(3) (2012) 2884-2892.

89. D. Russo and V. Birolini, A TRIZ based method for making systematic innovation in Ecodesign, Int. Journal of Systematic Innovation 2(1) (2012) 22-32.

90. S. Negny, J.P. Belaud, G.C. Robles, E.R. Reyes, J.B. Ferrer, Toward an eco-innovative method based on a better use of resources: application to chemical process preliminary design, Journal of Cleaner Production 32 (2012) 101-113.

91. X. Durieux, H. Teulon, Eco-Design and Innovation on IT Services: a Business Look. IEEE 2012 Electronics Goes Green 2012+, IEEE, USA, (2012). 
92. Hosseinpour, and Q. Peng, Sustainable Design Using Integrated TRIZ and Eco-Checklist with Function Impact Matrix, ASME 2012 International Design, (2012) pp. 633-642, doi:10.1115/DETC2012-70431.

93. A. Mogensen, G. Rousse, Paths to improving the environmental performance of lithium-ion batteries: from eco-design to eco-innovation, In: Electronics Goes Green 2012+, IEEE, USA (2012).

94. W.S. Kallel, Y. Ledoux, J-P. Nadeau, Eco-innovative Method to Improve the Distribution Phase of Product, IEEE, USA, (2013).

95. A. Cherifi, M. Dubois, M. Gardoni, A. Tairi, A catalyst method for an innovative Eco-design strategy using TRIZ approach, Current Journal of Applied Science and Technology 4 (29) (2014) 4156-4174.

96. W.-C. Chen, J.L. Chen, Eco-innovation by Integrating Biomimetic Design and ARIZ, Procedia CIRP, Volume 15, (2014) p. 401-406, https://doi.org/10.1016/j.procir.2014.06.028.

97. F.Z. Ben Moussa, S. Dubois, R. De Guio, I. Rasovska, R. Benmoussa, N. Gartiser, How can TRIZ contribute to solve the problems of green logistics?, International Conference on Green Supply Chain, GSC'14, Arras, France, Jun 2014.

98. R. Vidal, J.L. Salmeron, A. Mena, V. Chulvi, Fuzzy Cognitive Map-based selection 1 of TRIZ trends for eco-innovation of ceramic industry products, Journal of Cleaner Production, Volume 107, (2015) Pages 202-214, https://doi.org/10.1016/j.jclepro.2015.04.131.

99. F. Cluzel, B. Yannou, D. Millet, Y. Leroy, Eco-ideation and eco-selection of R\&D projects portfolio in complex systems industries, Journal of Cleaner Production 112 (5) (2016) 43294343.

100. Y.T. Ko, M.S. Chen, C.C. Lu, A Systematic-Innovation design approach for green product. Intern. Journal of Construction Engineering and Management 5 (4) (2016) 102-107.

101. P-E. Fayemi, C. Vitoux, M. Schöfer, G. Bersano, Using TRIZ to Combine Advantages of Different Concepts in an Eco-Design Process, In: Setchi, R., Howlett. Liu, Y. Theobald, P. (eds.), Sustainable Design and Manufacturing, Springer, (2016) pp. 513-524.

102. Lhoussaine Ameknassi, Daoud Ait-Kadi, Samira Keivanpour, Incorporating Design for Environment into Product Development Process: An Integrated Approach, IFACPapersOnLine, Vol. 49, Issue 12, (2016) pp. 1460-1465, https://doi.org/10.1016/j.ifacol.2016.07.777.

103. F.Z. Ben Moussa, I. Rasovska, S. Dubois, R. De Guio, R. Benmoussa, Reviewing the use of the theory of inventive problem solving (TRIZ) in green supply chain problems, Journal of Cleaner Production, Volume 142, Part 4, (2017) Pages 2677-2692, https://doi.org/10.1016/j.jclepro.2016.11.008.

104. J.L. Chen, S-H. Hung, Eco-Innovation by TRIZ and Biomimetics Design. Proceedings of the 2017 IEEE International Conference on Applied System Innovation, IEEE-ICASI, (2017), DOI: 10.1109/ICASI.2017.7988340.

105. G. Bersano, P.E. Fayemi, M. Schoefer, C. Spreafico, An Eco-Design Methodology Based on a-LCA and TRIZ, In: Campana G., Howlett R., Setchi R., Cimatti B. (eds) Sustainable Design and Manufacturing 2017, SDM 2017, Smart Innovation, Systems and Technologies, vol 68, Springer, Cham, (2017), https://doi.org/10.1007/978-3-319-57078-5_86.

106. G. Caligiana, A. Liverani, D. Francia, L. Frizziero, G. Donnici, QFD and TRIZ to Sustain the Design of Direct Open Moulds, In: Campana G., Howlett R., Setchi R., Cimatti B. (eds) Sustainable Design and Manufacturing 2017, SDM 2017, Smart Innovation, Systems and Technologies, vol 68. Springer, Cham, (2017).

107. D. Russo, C. Rizzi, C. Spreafico, How to Build Guidelines for Eco-Improvement, In: Campana G., Howlett R., Setchi R., Cimatti B. (eds) Sustainable Design and Manufacturing 
2017. SDM 2017. Smart Innovation, Systems and Technologies, vol 68. Springer, Cham, (2017).

108. H.-C. Chen, Green Innovation Design Model of Kansei Engineering, Proceedings of the 7th International Conference on Kansei Engineering and Emotion Research 2018, Advances in Intelligent Systems and Computing, Eds. Anitawati Mohd Lokman, Toshimasa Yamanaka, Pierre Lévy, Kuohsiang Chen, Shinichi Koyama, (2018) pp. 267-276, ISBN 9789811086120.

109. P. Livotov, A.P. Chandra Sekaran, Mas'udah, et al., Environmental Problems and Inventive Solution Principles in Process Engineering. Proceedings of the $18^{\text {th }}$ TRIZ Future Conference "Towards automated inventions for smart industries", 29-31.10.2018, Strasbourg, France, Strasbourg University, (2018).

110. P. Livotov, Mas'udah, A.P. Chandra Sekaran, On the Efficiency of TRIZ Application for Process Intensification in Process Engineering. in: Cavallucci D., De Guio R., Koziołek S. (eds) Automated Invention for Smart Industries, TFC 2018, IFIP Advances in Information and Communication Technology, vol 541, Springer, Cham, (2018), pp.126-140, http://dx.doi.org/10.1007/978-3-030-02456-7_11. 